\title{
Cupping therapy and chronic back pain: systematic review and meta-analysis
}

\author{
Caroline de Castro Moura ${ }^{1}$ \\ Érika de Cássia Lopes Chaves ${ }^{2}$ \\ Ana Carolina Lima Ramos Cardoso ${ }^{1}$ \\ Denismar Alves Nogueira ${ }^{3}$ \\ Hérica Pinheiro Corrêa ${ }^{1}$ \\ Tânia Couto Machado Chianca ${ }^{1}$
}

\begin{abstract}
Objectives: to evaluate the evidence from the literature regarding the effects of cupping therapy on chronic back pain in adults, the most used outcomes to evaluate this condition, the protocol used to apply the intervention and to investigate the effectiveness of cupping therapy on the intensity of chronic back pain. Method: systematic review and meta-analysis carried out by two independent researchers in national and international databases. Reference lists of systematic reviews were also explored. The quality of evidence was assessed according to the Jadad scale. Results: 611 studies were identified, of which 16 were included in the qualitative analysis and 10 in the quantitative analysis. Cupping therapy has shown positive results on chronic back pain. There is no standardization in the treatment protocol. The main assessed outcomes were pain intensity, physical incapacity, quality of life and nociceptive threshold before the mechanical stimulus. There was a significant reduction in the pain intensity score through the use of cupping therapy ( $p=0.001)$. Conclusion: cupping therapy is a promising method for the treatment of chronic back pain in adults. There is the need to establish standardized application protocols for this intervention.
\end{abstract}

Descriptors: Review; Chronic Pain; Back Pain; Cupping Therapy; Meta-Analysis; Nursing.

\footnotetext{
Universidade Federal de Minas Gerais, Escola de Enfermagem, Belo Horizonte, MG, Brazil.

2 Universidade Federal de Alfenas, Escola de Enfermagem, Alfenas, MG, Brazil.

${ }^{3}$ Universidade Federal de Alfenas, Instituto de Ciências Exatas, Alfenas, MG, Brazil.
}

\section{How to cite this article}

Moura CC, Chaves ECL, Cardoso ACLR, Nogueira DA, Corrêa HP, Chianca TCM. Cupping therapy and chronic back pain: systematic review and meta-analysis. Rev. Latino-Am. Enfermagem. 2018;26:e3094. [Access ‘ + — _ ]; Available in: DOI: http://dx.doi.org/10.1590/1518-8345.2888.3094. month day year 


\section{Introduction}

Chronic back pain causes physical, emotional and socioeconomic changes ${ }^{(1-3)}$ and, consequently, high use of medicines and health resources ${ }^{(4)}$. The search for demedicalization leads to an increasing use of integrative and complementary practices, such as Traditional Chinese Medicine (TCM) resources, to complement pain-related allopathic care ${ }^{(5)}$. Cupping therapy is one of the recommended TCM therapies for chronic pain reduction(6). It involves the application of cups of different materials $^{(7)}$ in an acupoint or area of pain by means of heat or vacuum apparatus(8).

The effect on pain reduction has not yet been fully elucidated(9), but different mechanisms of action, based on several assumptions ${ }^{(10)}$, are attributed to cupping therapy, such as the metabolic, neuronal hypotheses $^{(9,11)}$ and TCM ${ }^{(12)}$. Evidence of the efficacy of this intervention is limited because of the lack of high quality, well-delineated randomized controlled trials $(\mathrm{RCTs})^{(6)}$ that result in validated and efficient protocols for the treatment of chronic back pain. Therefore, this study aims to evaluate the literature evidence regarding the effects of cupping therapy on chronic back pain in adults compared to sham, active treatment, waiting list, standard medical treatment or no treatment, outcomes most commonly used to assess this condition, the protocol used to apply the intervention and subsequently investigate the effectiveness of cupping therapy on the intensity of chronic back pain.

\section{Method}

A systematic review of the literature was performed, followed by meta-analysis, used to determine the intensity of back pain in adult clients. The study was based on the criteria of the Preferred Reporting Items for Systematic Reviews and Meta-Analyzes (PRISMA Statement)(13).

The PICO ( $\mathrm{P}$ - population; I - intervention; C comparison; O - outcomes) ${ }^{(14)}$ guided the elaboration of the guiding question: "What are the effects of cupping therapy on adults with chronic back pain?"

The search strategy, carried out by two independent reviewers from June 2017 to May 2018 was based on the following databases: Medical Literature Analysis and Retrieval System Online (MEDLINE) via the US National Library of Medicine National Institutes of Health (PUBMED), Web of Science, The Cumulative Index to Nursing and Allied Health Literature (CINAHL), Physiotherapy Evidence Database (PEDro), Embase, Scopus, as well as databases indexed in the Virtual Health Library (VHL), such as Latin American \&
Caribbean Health Sciences Literature (LILACS) and the National Information Center of Medical Sciences of Cuba (CUMED). Reference lists of systematic reviews were also explored in the search for relevant studies related to the guiding question.

The terms, controlled and free, were combined by means of the Boolean operators OR and AND as follows: ("Back Pain" OR "Low Back Pain" OR "Sciatica" OR "Chronic Pain" OR "Musculoskeletal Pain" OR Myalgia OR "Neck Pain" OR "Low Back Pains" OR "Musculoskeletal Pains" OR "Muscle Pain" OR "Neck Pains" OR "Cervical Pain" OR "Cervical Pains" OR Lumbago OR "lumbar pain") AND ("cupping therapy" OR cupping OR cups).

The eligibility criteria for the selection of articles were: RCT with adults (18 years or older); chronic pain (for three months or more) ${ }^{(15)}$ in at least one of the segments of the spine (cervical, thoracic and/or lumbar); use of cupping therapy (dry, wet, massage, flash) ${ }^{(7)}$ compared to one or more of the following groups: sham, active treatment, waiting list, standard medical treatment, or no treatment. We excluded studies that did not present online abstract in full for analysis, those that were not located by any means and studies with pregnant women.

In order to collect the information from the selected studies, we used an adapted form ${ }^{(16)}$ in accordance with the recommendations of the Revised Standards for Reporting Interventions in Clinical Trials of Acupuncture (STRICTA) ${ }^{(17)}$ and the classifications of cupping therapy ${ }^{(7,18)}$.

The following data were extracted: article identification (title, author (s)/training area, journal, year of publication, study country/language); objectives; methodological characteristics (design, sample size and loss of follow-up; inclusion and exclusion criteria); clinical data (number of patients by sex, mean age, diagnosis, duration of symptoms); description of interventions in the follow-up groups (number of sessions, duration of treatment, type of technique applied (dry, wet, flash or massage cupping), application device, time of stay of the device, suction method (manual, fire, automatic-electric)/suction strength (light, medium, strong or pulsating) ${ }^{(18)}$; peculiarities of the intervention; application points; training area of the professional who carried out the intervention; years of experience in the area); outcomes and methods of evaluation (number of evaluations, intervals between them, measurement tools); data analysis; main results; and study findings.

The methodological quality of eligible studies was assessed using the Jadad scale ${ }^{(19)}$, which is centered on internal validity. The questions have a yes/no answer option with a total score of five points: three times one point for the yes responses and two additional points for appropriate randomization and concealment of allocation 
methods. Two independent reviewers conducted the evaluation, and a third investigator was consulted to solve possible disagreements.

Data analyzes were performed using Stata SE/12.0 statistical software. The absolute difference between means with $95 \%$ confidence intervals was selected to describe the mean differences between the treated and control groups in the evaluation performed shortly after treatment. P-value < 0.05 was considered as statistically significant. Potential heterogeneity among the studies was examined using Cochran $\mathrm{Q}^{(20)}$ and $\mathrm{I}^{2(21)}$ statistics. Since there was statistical significance in the test for heterogeneity of the results $(p<0.05)$ and the calculated value of $\mathrm{I}^{2}$ suggested a moderate to high heterogeneity
$(67.7 \%)^{(21)}$, the random effects model was adopted for the analysis.

\section{Results}

A total of 614 studies were found in electronic and manual searches. Of these, 296 were removed from the list because they were duplicates. After reviewing titles and abstracts, 265 studies were excluded and 53 remained for analysis of the full text. Of these, 11 studies were not found (online, via bibliographic switching or direct contact with authors) and 26 articles were excluded. Finally, 16 articles remained in the review for the synthesis of the qualitative analysis and 10 articles entered the quantitative analysis (Figure 1 ).

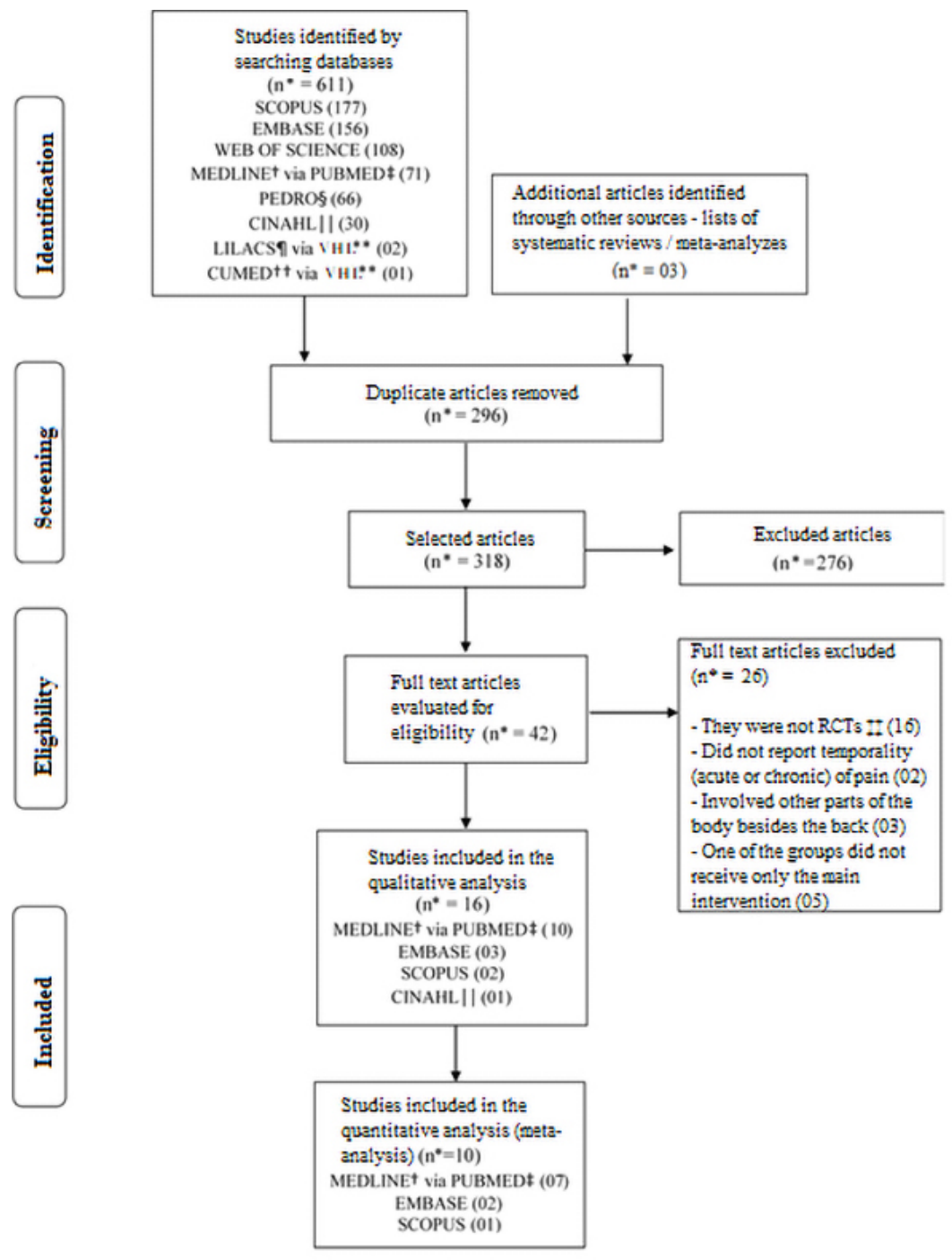

*n - Number of articles; +MEDLINE - Medical Literature Analysis and Retrieval System Online; ¥PUDMED - US National Library of Medicine National Institutes of Health; §PEDRO - Physiotherapy Evidence Database; IICINAHL - The Cumulative Index to Nursing and Allied Health Literature; ILILACS - Latin American and Caribbean Health Sciences Literature; **VHL - Virtual Health Library; †+CUMED - National Information Center of Medical Sciences of Cuba; $\neq \neq R C T$ Randomized Clinical Trial

Figure 1 - Flowchart of literature search and selection process. Belo Horizonte, MG, Brazil, 2018 


\begin{tabular}{|c|c|c|c|c|}
\hline $\begin{array}{c}\text { Study } \\
\text { identification }\end{array}$ & Objective & $\begin{array}{l}\text { Intervention in the } \\
\text { experimental group }\end{array}$ & $\begin{array}{l}\text { Intervention in the } \\
\text { control group }\end{array}$ & Main findings \\
\hline $\begin{array}{l}\text { Teut M et al. } \\
(2018)^{(22)}\end{array}$ & $\begin{array}{l}\text { To investigate the effectiveness of } \\
\text { Dry Pulsatile Cupping in reducing } \\
\text { pain and improving back function } \\
\text { and quality of life in patients } \\
\text { with chronic nonspecific low } \\
\text { back pain. }\end{array}$ & $\begin{array}{l}\text { Pulsatile cupping with } \\
\text { strong negative pressure } \\
\text { and paracetamol on } \\
\text { demand }\left(\mathrm{n}^{*}=37\right) \\
\text { Pulsatile cupping with } \\
\text { weak negative pressure } \\
\text { and paracetamol on } \\
\text { demand (minimal } \\
\text { cupping) }(n=36)\end{array}$ & $\begin{array}{l}\text { Paracetamol (maximum } \\
\text { dose of } 4 \text { times, } 500 \\
\text { milligrams per day) on } \\
\text { demand }\left(n^{*}=37\right)\end{array}$ & $\begin{array}{l}\text { Both suction cup forms were effective } \\
\text { in chronic nonspecific low back pain, } \\
\text { without showing significant differences } \\
\text { in the direct comparison after four } \\
\text { weeks. Only pulsatile suction cups } \\
\text { showed effects compared to controls } \\
\text { after } 12 \text { weeks. }\end{array}$ \\
\hline $\begin{array}{l}\text { Saha FJ et al. } \\
(2017)^{(23)}\end{array}$ & $\begin{array}{l}\text { To test the effectiveness of } \\
\text { Cupping Massage in patients with } \\
\text { neck pain. }\end{array}$ & Cupping massage $\left(n^{*}=25\right)$ & $\begin{array}{l}\text { Waiting list (patients } \\
\text { were asked to } \\
\text { continue medical } \\
\text { care, but refrain from } \\
\text { invasive treatments, } \\
\text { such as injections or } \\
\text { acupuncture) }\left(\mathrm{n}^{*}=25\right)\end{array}$ & $\begin{array}{l}\text { Cupping massage appears to } \\
\text { be effective in reducing pain and } \\
\text { increasing function and quality of life } \\
\text { in patients with chronic nonspecific } \\
\text { cervical pain. }\end{array}$ \\
\hline $\begin{array}{l}\text { Lin ML et al. } \\
(2017)^{(28)}\end{array}$ & $\begin{array}{l}\text { To evaluate the effectiveness of } \\
\text { laser acupuncture associated } \\
\text { with Chinese cupping therapy in } \\
\text { the treatment of low back pain. }\end{array}$ & $\begin{array}{l}\text { Laser acupuncture and } \\
\text { Chinese cupping }\left(n^{*}=25\right)\end{array}$ & $\begin{array}{l}\text { Sham Laser and } \\
\text { Chinese cupping } \\
\left(\mathrm{n}^{*}=23\right)\end{array}$ & $\begin{array}{l}\text { Laser acupuncture combined with } \\
\text { Chinese cupping therapy at the } \\
\text { acupuncture points } \mathrm{B}^{\dagger} 40 \text { and } A \text { shi } \\
\text { effectively reduces low back pain. } \\
\text { Changes in plasma cortisol levels } \\
\text { have indicated that laser acupuncture } \\
\text { combined with Chinese cupping } \\
\text { therapy is an effective treatment for } \\
\text { pain relief. }\end{array}$ \\
\hline $\begin{array}{l}\text { Yazdanpanahi } \\
\text { Z et al. (2017) } \\
\text { (31) }\end{array}$ & $\begin{array}{l}\text { To evaluate the effects of } \\
\text { acupuncture approaches on the } \\
\text { severity of postpartum low back } \\
\text { pain among primiparous women } \\
\text { visiting selected educational } \\
\text { centers affiliated with the } \\
\text { University of Medical Sciences of } \\
\text { Shiraz, Shiraz, Iran. }\end{array}$ & Cupping therapy $\left(n^{*}=50\right)$ & $\begin{array}{l}\text { Acupressure }\left(n^{*}=50\right) \\
\text { Control group without } \\
\text { intervention }\left(n^{*}=50\right)\end{array}$ & $\begin{array}{l}\text { Although pain intensity decreased } \\
\text { in both groups, this reduction was } \\
\text { significant in the cupping therapy } \\
\text { group. Therefore, both cupping } \\
\text { therapy and acupressure may be } \\
\text { effective in reducing postpartum low } \\
\text { back pain in primiparous women. }\end{array}$ \\
\hline $\begin{array}{l}\text { Chi LM et al. } \\
(2016)^{(29)}\end{array}$ & $\begin{array}{l}\text { To investigate the efficacy of } \\
\text { cupping therapy in relieving chronic } \\
\text { neck and shoulder pain among } \\
\text { community residents and changes } \\
\text { in skin surface temperature. }\end{array}$ & Cupping therapy $\left(\mathrm{n}^{*}=30\right)$ & $\begin{array}{l}\text { Control group without } \\
\text { intervention }\left(n^{*}=30\right)\end{array}$ & $\begin{array}{l}\text { Cupping therapy increased the surface } \\
\text { temperature of the skin and reduced } \\
\text { systemic blood pressure. The subjective } \\
\text { experience of pain intensity also } \\
\text { reduced. Cupping therapy resembles } \\
\text { an analgesic effect that has no known } \\
\text { negative side effects and can be } \\
\text { considered safe. }\end{array}$ \\
\hline $\begin{array}{l}\text { AlBedah A et al. } \\
(2015)^{(36)}\end{array}$ & $\begin{array}{l}\text { To assess the effectiveness } \\
\text { and safety of Wet Cupping as } \\
\text { a treatment for persistent and } \\
\text { nonspecific low back pain. }\end{array}$ & $\begin{array}{l}\text { Wet cupping and analgesic } \\
\text { drug (maximum of three } \\
500 \text { mg acetaminophen } \\
\text { tablets per day) }\left(n^{*}=40\right)\end{array}$ & $\begin{array}{l}\text { Analgesic drug } \\
\text { (maximum of three } \\
500 \mathrm{mg} \text { acetaminophen } \\
\text { tablets milligrams per } \\
\text { day) }\left(\mathrm{n}^{*}=40\right)\end{array}$ & $\begin{array}{l}\text { Wet cupping works to reduce pain } \\
\text { and improve disability associated with } \\
\text { nonspecific and persistent low back } \\
\text { pain for at least } 2 \text { weeks after the end of } \\
\text { the intervention. }\end{array}$ \\
\hline $\begin{array}{l}\text { Emerich M et al. } \\
(2014)^{(9)}\end{array}$ & $\begin{array}{l}\text { To measure, in parallel, the } \\
\text { metabolic changes in the tissue } \\
\text { under the glass cups and the } \\
\text { pressure pain threshold. }\end{array}$ & Dry cupping $\left(n^{*}=12\right)$ & $\begin{array}{l}\text { Comparison between the } \\
\text { side on which cupping } \\
\text { therapy was performed } \\
\text { with the contralateral } \\
\text { side, which did not } \\
\text { receive the intervention } \\
\left(\mathrm{n}^{*}=12\right) \\
\end{array}$ & $\begin{array}{l}\text { Cupping therapy promotes anaerobic } \\
\text { metabolism lasting } 280 \text { minutes in the } \\
\text { subcutaneous tissue and increases the } \\
\text { immediate pressure pain thresholds in } \\
\text { some areas. }\end{array}$ \\
\hline $\begin{array}{l}\text { Akbarzadeh M } \\
\text { et al. }(2014)^{(32)}\end{array}$ & $\begin{array}{l}\text { To investigate the effect of Dry } \\
\text { Cupping at point } B^{\dagger} 23 \text { on the } \\
\text { intensity of low back pain in } \\
\text { primiparous women. }\end{array}$ & Dry Cupping $\left(n^{*}=50\right)$ & $\begin{array}{l}\text { Routine care and referral } \\
\text { to a specialist in case of } \\
\text { severe pain }\left(n^{*}=50\right)\end{array}$ & $\begin{array}{l}\text { Dry cupping in acupoint } \mathrm{B}^{\dagger} 23 \text { had a } \\
\text { desirable effect on reducing pain in } \\
\text { patients. The VAS } \text { scores agreed with }^{\ddagger} \text { those of the McGill short questionnaire. }\end{array}$ \\
\hline $\begin{array}{l}\text { Lauche R et al. } \\
(2013)^{(24)}\end{array}$ & $\begin{array}{l}\text { To test the effectiveness of } \\
12 \text { weeks of Cupping Massage } \\
\text { performed at home, compared to } \\
\text { the same period of progressive } \\
\text { muscle relaxation in patients with } \\
\text { chronic nonspecific neck pain. }\end{array}$ & Cupping massage $\left(n^{*}=30\right)$ & $\begin{array}{l}\text { Instructions and training } \\
\text { to perform progressive } \\
\text { muscle relaxation at } \\
\text { home twice a week, } 20 \\
\text { minutes per session, and } \\
\text { to record this practice in } \\
\text { a journal }\left(n^{*}=31\right)\end{array}$ & $\begin{array}{l}\text { Cupping massage is no more effective } \\
\text { than progressive muscle relaxation } \\
\text { in reducing chronic nonspecific neck } \\
\text { pain. Both therapies can be easily } \\
\text { used at home and can reduce pain to } \\
\text { a clinically relevant minimum extent. } \\
\text { However, cupping massage is better } \\
\text { than progressive muscle relaxation in } \\
\text { improving well-being and decreasing } \\
\text { sensitivity to pressure pain. }\end{array}$ \\
\hline $\begin{array}{l}\text { Kim TH et al. } \\
(2012)^{(34)}\end{array}$ & $\begin{array}{l}\text { To compare the effects of cupping } \\
\text { therapy and the "heated pad" on } \\
\text { neck pain, functional disability } \\
\text { and quality of life in video display } \\
\text { terminal workers. }\end{array}$ & Cupping therapy $\left(\mathrm{n}^{*}=20\right)$ & $\begin{array}{l}\text { Heated hot water pads } \\
\text { applied to the neck and } \\
\text { upper trapezius muscle } \\
\text { for } 10 \text { minutes, } 3 \text { times } \\
\text { a week, for } 2 \text { weeks } \\
\left(\mathrm{n}^{*}=20\right)\end{array}$ & $\begin{array}{l}2 \text { weeks of cupping therapy associated } \\
\text { with an exercise program may be } \\
\text { effective in reducing pain and improving } \\
\text { neck function in workers at Video } \\
\text { Display Terminal. }\end{array}$ \\
\hline
\end{tabular}




\begin{tabular}{|c|c|c|c|c|}
\hline $\begin{array}{c}\text { Study } \\
\text { identification }\end{array}$ & Objective & $\begin{array}{l}\text { Intervention in the } \\
\text { experimental group }\end{array}$ & $\begin{array}{l}\text { Intervention in the } \\
\text { control group }\end{array}$ & Main findings \\
\hline $\begin{array}{l}\text { Lauche R et al. } \\
(2012)^{(25)}\end{array}$ & $\begin{array}{l}\text { To test the efficacy of a single } \\
\text { traditional cupping therapy } \\
\text { treatment in patients with chronic } \\
\text { nonspecific chronic neck pain. }\end{array}$ & $\begin{array}{l}\text { Cupping therapy and } \\
\text { non-steroid medication for } \\
\text { pain and physical therapy } \\
\left(\mathrm{n}^{*}=22\right)\end{array}$ & $\begin{array}{l}\text { Non-steroid medication } \\
\text { for pain and physical } \\
\text { therapy (in both groups) } \\
\left(\mathrm{n}^{\star}=23\right)\end{array}$ & $\begin{array}{l}\text { A single application of cupping therapy } \\
\text { may be effective in the treatment of } \\
\text { chronic nonspecific cervical pain. }\end{array}$ \\
\hline $\begin{array}{l}\text { Lin ML et al. } \\
(2012)^{(30)}\end{array}$ & $\begin{array}{l}\text { To evaluate the effect of laser } \\
\text { acupuncture and soft cupping on } \\
\text { low back pain. }\end{array}$ & $\begin{array}{l}\text { Laser acupuncture and soft } \\
\text { cupping }\left(\mathrm{n}^{*}=28\right)\end{array}$ & $\begin{array}{l}\text { Soft cupping and laser } \\
\text { without radiation }\left(n^{*}=29\right)\end{array}$ & $\begin{array}{l}\text { Laser acupuncture and mild cupping } \\
\text { therapy may be a suitable treatment for } \\
\text { patients with low back pain. }\end{array}$ \\
\hline $\begin{array}{l}\text { Cramer H et al. } \\
(2011)^{(26)}\end{array}$ & $\begin{array}{l}\text { To compare the effects of a series } \\
\text { of } 5 \text { sessions of Pulsating Cupping } \\
\text { with standard medical care in } \\
\text { relieving chronic nonspecific } \\
\text { cervical pain. }\end{array}$ & Pulsating Cupping $\left(n^{*}=24\right)$ & $\begin{array}{l}\text { Self-directed standard } \\
\text { medical care (physical } \\
\text { therapy, exercises and } \\
\text { analgesic drugs as } \\
\text { needed) }\left(n^{*}=24\right)\end{array}$ & $\begin{array}{l}\text { Pneumatic pulsation therapy appears } \\
\text { to be a safe and effective method to } \\
\text { relieve pain and improve function and } \\
\text { quality of life in patients with chronic } \\
\text { neck pain. }\end{array}$ \\
\hline $\begin{array}{l}\text { Kim Jl et al. } \\
(2011)^{(35)}\end{array}$ & $\begin{array}{l}\text { To determine the efficacy and } \\
\text { safety of Wet Cupping treatment } \\
\text { for persistent nonspecific low } \\
\text { back pain. }\end{array}$ & Wet-cupping $\left(n^{*}=21\right)$ & $\begin{array}{l}\text { Usual care (booklets for } \\
\text { exercise, general advice } \\
\text { for nonspecific and } \\
\text { persistent low back pain, } \\
\text { and acetaminophen) in } \\
\text { both groups }\left(\mathrm{n}^{*}=11\right)\end{array}$ & $\begin{array}{l}\text { Wet cupping may have a potential } \\
\text { effect on reducing pain associated } \\
\text { with nonspecific and persistent low } \\
\text { back pain. }\end{array}$ \\
\hline $\begin{array}{l}\text { Lauche R et al. } \\
(2011)^{(27)}\end{array}$ & $\begin{array}{l}\text { To determine whether a number } \\
\text { of cupping treatments effectively } \\
\text { relieves chronic nonspecific } \\
\text { cervical pain. In addition, the } \\
\text { subjects' mechanical thresholds } \\
\text { were measured to determine } \\
\text { whether cupping therapy has an } \\
\text { effect on mechanical hyperalgesia } \\
\text { in patients with chronic neck pain. }\end{array}$ & $\begin{array}{l}\text { Cupping therapy and } \\
\text { non-steroid medication for } \\
\text { pain and physical therapy } \\
\left(\mathrm{n}^{*}=22\right)\end{array}$ & $\begin{array}{l}\text { Non-steroid medication } \\
\text { for pain and physical } \\
\text { therapy }\left(n^{*}=24\right)\end{array}$ & $\begin{array}{l}\text { Five dry cupping sessions appear to be } \\
\text { safe and effective in the treatment of } \\
\text { chronic nonspecific cervical pain. }\end{array}$ \\
\hline $\begin{array}{l}\text { Farhadi K et al. } \\
(2009)^{(33)}\end{array}$ & $\begin{array}{l}\text { To determine the effectiveness } \\
\text { of Wet Cupping for the treatment } \\
\text { of persistent and nonspecific low } \\
\text { back pain. }\end{array}$ & Wet cupping (*n=48) & $\begin{array}{l}\text { Usual care, combination } \\
\text { of medication and } \\
\text { exercises }\left(n^{*}=50\right)\end{array}$ & $\begin{array}{l}\text { Wet cupping is associated with greater } \\
\text { short-term clinical benefit compared to } \\
\text { usual care. }\end{array}$ \\
\hline
\end{tabular}

$*_{n}$ - Number of participants; †B - Bladder; $\neq$ VAS - Visual Analogue Scale.

Figure 2 - Characterization of the studies regarding the applied intervention, Belo Horizonte, MG, Brazil, 2018 ( $n=16$ )

All articles selected were published in English language and were conducted in Germany(9,22-27), Taiwan(28-30), Iran (31-33), South Korea ${ }^{(34-35)}$ and in Saudi Arabia ${ }^{(36)}$. Participants were a total of 1049 people, aged between 18 and 79 years, of whom 519 were in the groups receiving the experimental therapy and 530 in the control groups (sham, waiting list, standard medical treatment/active treatment or no treatment). Of these, all had chronic pain conditions ${ }^{(15)}$, being the cervical spine/neck the most affected area ${ }^{(9,23-27,29,34)}$, followed by the lumbar region(22,28,30-33,35-36). Two other studies(31,33), although they did not make clear the temporality of the pain, were selected because this information could be inferred with great accuracy.

The characterization of the studies regarding the objective, the interventions applied in the experimental and control groups, and the main findings are presented in Figure 2.

Regarding the methodological quality of the RCTs, all reported the random sequence generation method and in only one study ${ }^{(9)}$ this process was not appropriate. In another study(30) there is not enough information to infer this information. Only in four $\mathrm{RCTs}^{(22,24,28-29)}$ there was a description of masking and in only two ${ }^{(22,28)}$ this was considered appropriate. Loss of follow-up was not described in only one RCT ${ }^{(29)}$.

Therefore, $6.25 \%(n=1)$ of the studies ${ }^{(9)}$ scored one on the Jadad score; $12.5 \%(n=2)^{(29-30)}$ scored two; $62.5 \%(n=10)^{(23,25-27,31-36)}$ scored three; $12.5 \%(n=2)$ $(22,24)$ score four; and $6.25 \%(n=1)^{(28)}$ scored five points.

The studied outcomes, the measurement tools, the number of evaluations and the interval between them are described in Figure 3.

The most evaluated outcomes were pain intensity $(100 \% ; n=16)^{(9,22-36)}$, followed by Physical disability $(62.5 \% ; n=10)^{(9,23-27,33-36)}$, quality of life $(37.5 \% ; n=6)$ (22-27) and nociceptive threshold before the mechanical stimulus, by means of an algometer $(37.5 \% ; n=6)^{(9,23-27)}$.

The number of evaluations ranged from two (baseline and after treatment) to 18 . Three studies performed evaluations between sessions( ${ }^{(9,28-29)}$; and 13 studies performed follow-up evaluations after the end of the treatment, ranging from two days to three months ${ }^{(9,22-}$ 23,25-27,30-36) (Figure 3).

The characteristics of the intervention protocol were based on the recommendations of the Revised Standards for Reporting Interventions in Clinical Trials of Acupuncture (STRICTA)(17) and in the classifications of cupping therapy ${ }^{(7,18)}$, which are described in Figure 4. 


\begin{tabular}{|c|c|c|c|}
\hline $\begin{array}{c}\text { Study } \\
\text { identification }\end{array}$ & Outcomes & Measurement Tools & $\begin{array}{l}\text { Number of evaluations/ } \\
\text { Interval between them }\end{array}$ \\
\hline $\begin{array}{l}\text { Teut M et al. } \\
(2018)^{(22)}\end{array}$ & $\begin{array}{l}\text { 1-Pain intensity } \\
\text { 2- Measure of back function } \\
\text { 3-Quality of life }\end{array}$ & $\begin{array}{l}\text { 1- VAS* }(0-100) \\
\text { 2-Funktionsfragebogen Hannover Rücken } \\
\text { 3- SF-36 }\end{array}$ & 03 (Baseline, after 4 and 12 weeks) \\
\hline $\begin{array}{l}\text { Saha FJ et al. } \\
(2017)^{(23)}\end{array}$ & $\begin{array}{l}\text { 1- Pain intensity } \\
\text { 2- Pain to the movement } \\
\text { 3-Physical disability } \\
\text { 4-Quality of life } \\
\text { 5- Nociceptive threshold } \\
\text { 6- Mechanical detection threshold } \\
\text { 7- Vibration detection threshold } \\
\text { 8- 2-point discrimination threshold }\end{array}$ & $\begin{array}{l}\text { 1- VAS* }(0-100) \\
\text { 2-Pain on Movement Questionnaire } \\
\text { 3-NDI } \\
\text { 4-SF-36 } \\
\text { 5- Algometer } \\
\text { 6- Von Frey filaments } \\
\text { 7-Diapason } \\
\text { 8- Pair of compasses with blunt ends }\end{array}$ & 02 (Baseline, 3 weeks after randomization) \\
\hline $\begin{array}{l}\text { Lin ML et al. } \\
(2017)^{(28)}\end{array}$ & $\begin{array}{l}\text { 1- Pain intensity } \\
\text { 2- Plasma cortisol level }\end{array}$ & 1-VAS* $(0-100)$ 2- Biological sample (blood) & $\begin{array}{l}02 \text { for cortisol (Baseline and after the } \\
\text { session) / } 06 \text { for VAS* (Baseline and } \\
\text { during session) }\end{array}$ \\
\hline $\begin{array}{l}\text { Yazdanpanahi Z et } \\
\text { al. }(2017)^{(31)}\end{array}$ & 1- Pain intensity & 1-Short-form McGill Pain Questionnaire & $\begin{array}{l}04 \text { (Baseline, immediately after, } 24 \text { hours } \\
\text { and } 2 \text { weeks after) }\end{array}$ \\
\hline $\begin{array}{l}\text { Chi LM et al. } \\
(2016)^{(29)}\end{array}$ & $\begin{array}{l}\text { 1- Pain intensity } \\
\text { 2- Tissue temperature } \\
\text { 3- Systemic arterial pressure }\end{array}$ & $\begin{array}{l}\text { 1-VAS* }(0-10) \\
\text { 2- Infrared Camera } \\
\text { 3- Mercury sphygmomanometer }\end{array}$ & $\begin{array}{l}02 \text { for pain intensity (Baseline and after } \\
\text { intervention) / } 04 \text { for tissue temperature } \\
\text { (5-minute interval between each } \\
\text { measurement) }\end{array}$ \\
\hline $\begin{array}{l}\text { AlBedah A et al. } \\
(2015)^{(36)}\end{array}$ & $\begin{array}{l}\text { Pain intensity } \\
\text { Physical disability }\end{array}$ & $\begin{array}{l}\text { 1-Numeric scale }(0-100) \\
\text { 1-PPI\$ 2-ODQ" }\end{array}$ & 03 (Baseline, after, follow-up of 2 weeks) \\
\hline $\begin{array}{l}\text { Emerich M et al. } \\
(2014)^{(9)}\end{array}$ & $\begin{array}{l}\text { 1- Pain intensity } \\
\text { 2-Physical disability } \\
\text { 3- Nociceptive threshold } \\
\text { 4- Pyruvate, Lactate, Glucose, Glycerin } \\
\text { and Adenosine }\end{array}$ & $\begin{array}{l}\text { 1/2-Neck Pain and Disability Scale } \\
\text { 3-Algometer 4- Microfilament with } \\
\text { semipermeable membrane (microdialysis) }\end{array}$ & $\begin{array}{l}04 \text { for algometer (baseline, immediately } \\
\text { after and } 140 \text { and } 280 \text { minutes after) / } 02 \\
\text { for Neck pain and disability scale (Baseline } \\
\text { and one week after / each } 20 \text { minutes } \\
\text { for microdialysis }\end{array}$ \\
\hline $\begin{array}{l}\text { Akbarzadeh M et } \\
\text { al. }(2014)^{(32)}\end{array}$ & $\begin{array}{l}\text { 1- Pain intensity } \\
\text { 2-Quality of pain }\end{array}$ & $\begin{array}{l}\text { 1- VAS* }(0-10) \\
\text { 2-Short-form McGill Pain Questionnaire }\end{array}$ & $\begin{array}{l}04 \text { (Baseline, immediately after, } 24 \text { hours } \\
\text { and } 2 \text { weeks after) }\end{array}$ \\
\hline $\begin{array}{l}\text { Lauche R et al. } \\
(2013)^{(24)}\end{array}$ & $\begin{array}{l}\text { 1- Pain intensity } \\
\text { 2- Perceived pain to the movement } \\
\text { 3-Quality of pain } \\
\text { 4-Physical disability } \\
\text { 5- Psychological distress } \\
\text { 6-Well-being } \\
\text { 7-Quality of life } \\
\text { 8- Nociceptive threshold }\end{array}$ & $\begin{array}{l}\text { 1- VAS }{ }^{*}(0-100) \\
\text { 2- Flexing, extending, flexing sideways and } \\
\text { rotating the neck laterally to the left and right } \\
\left(V^{*}{ }^{*}\right) \\
\text { 3-Pain Description List } \\
\text { 4-NDI } \\
\text { 5-Hospital Anxiety and Depression Scale } \\
\text { 6-Questionnaire on the Assessment of } \\
\text { Physical Well-being } \\
\text { 7-SF-36 } \\
\text { 8-Algometer }\end{array}$ & 02 (Baseline, week 12) \\
\hline $\begin{array}{l}\text { Kim TH et al. } \\
(2012)^{(34)}\end{array}$ & $\begin{array}{l}\text { 1- Pain intensity } \\
\text { 2-Physical disability } \\
\text { 3- Physiological and psychological } \\
\text { symptoms } \\
\text { 4- Range of motion } \\
\end{array}$ & $\begin{array}{l}\text { 1- Numeric scale }(0-100) \\
\text { 2-NDI } \\
\text { 3-Measure yourself medical outcome profile } \\
2 \text { score } \\
\text { 4-Cervical range of motion instrument }\end{array}$ & 03 (Baseline, 3 weeks, 7 weeks) \\
\hline $\begin{array}{l}\text { Lauche R et al. } \\
(2012)^{(25)}\end{array}$ & $\begin{array}{l}\text { 1- Pain intensity } \\
\text { 2- Physical disability } \\
\text { 3-Quality of life } \\
\text { 4- Nociceptive threshold }\end{array}$ & 1-VAS* $(0-100)$ 2-NDI ${ }^{\ddagger} 3-S F-36+4$-Algometer & 02 (Baseline and 3 days after) \\
\hline $\begin{array}{l}\text { Lin ML et al. } \\
(2012)^{(30)}\end{array}$ & $\begin{array}{l}\text { 1- Pain intensity } \\
\text { 2- Electrical current of the meridians }\end{array}$ & 1-VAS* (0-10) 2-Ryodoraku & $\begin{array}{l}05 \text { (Assessments for } 5 \text { consecutive days - } \\
2 \text { before and } 2 \text { after) }\end{array}$ \\
\hline $\begin{array}{l}\text { Cramer H et al. } \\
(2011)^{(26)}\end{array}$ & $\begin{array}{l}\text { 1- Pain intensity } \\
\text { 2- Pain to the movement } \\
\text { 3-Physical disability } \\
\text { 4-Quality of life } \\
\text { 5- Nociceptive threshold } \\
\text { 6- Mechanical detection threshold } \\
\text { 7- Vibration detection threshold }\end{array}$ & $\begin{array}{l}\text { 1-Numeric scale }(0-10) \\
\text { 2- VAS* }(0-10) \\
\text { 3-NDI } \\
\text { 4-SF-36 } \\
\text { 5-Algometer } \\
\text { 6- Von Frey filaments } \\
\text { 7-Diapason }\end{array}$ & $\begin{array}{l}02 \text { (Baseline and } 2.5 \text { weeks after baseline } \\
\text { assessment) }\end{array}$ \\
\hline $\begin{array}{l}\text { Kim Jl et al. } \\
(2011)^{(35)}\end{array}$ & $\begin{array}{l}\text { 1-Pain intensity } \\
\text { 2-Physical disability }\end{array}$ & $\begin{array}{l}\text { 1- Numeric scale }(0-100) \\
1-\left.P P\right|^{\S} \\
2-O D Q \|\end{array}$ & 03 (Baseline, after, follow-up of 2 weeks) \\
\hline $\begin{array}{l}\text { Lauche R et al. } \\
(2011)^{(27)}\end{array}$ & $\begin{array}{l}\text { 1- Pain intensity } \\
\text { 2- Pain at rest and pain to the movement } \\
\text { 3-Physical disability } \\
\text { 4-Quality of life } \\
\text { 5- Nociceptive threshold } \\
\text { 6- Vibration detection threshold } \\
\text { 7- Mechanical detection threshold }\end{array}$ & $\begin{array}{l}\text { 1-Numeric scale }(0-10) \\
\text { 2- VAS* }{ }^{*}(0-100) \\
\text { 3-NDI } \\
\text { 4-SF-36 }{ }^{\dagger} \text { 5-Algometer } \\
\text { 6-Diapason } \\
\text { 7- Von Frey filaments }\end{array}$ & $\begin{array}{l}02 \text { (Baseline and } 18 \text { days after } \\
\text { first assessment) }\end{array}$ \\
\hline $\begin{array}{l}\text { Farhadi K et al. } \\
(2009)^{(33)}\end{array}$ & $\begin{array}{l}\text { 1- Pain intensity } \\
\text { 2-Physical disability } \\
\text { 3- Medication use }\end{array}$ & $\begin{array}{l}\text { 1-PPI\$ } \\
\text { 2-ODQ\| } \\
\text { 3-Medication Quantification Scale }\end{array}$ & $\begin{array}{l}02 \text { (Baseline and after three months of } \\
\text { follow-up) }\end{array}$ \\
\hline
\end{tabular}

*VAS - Visual Analogue Scale; +SF-36 - Short Form 36 Health Survey Questionnaire; ‡NDI - Neck Disability Index; §PPI- McGill Present Pain Intensity questionnaire; IIODQ - Oswestry Disability Questionnaire

Figure 3 - Evaluated outcomes, measurement tools, number of evaluations and interval between them. Belo Horizonte, MG, Brazil, 2018. $(n=16)$ 


\begin{tabular}{|c|c|c|c|c|c|c|c|c|c|}
\hline 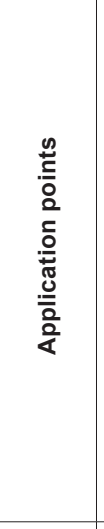 & 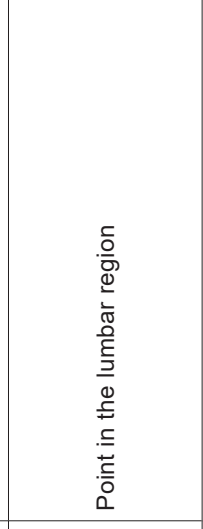 & 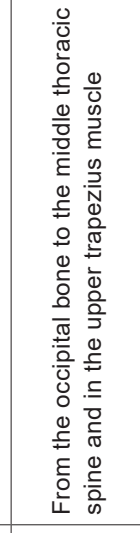 & 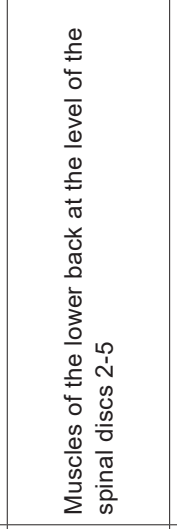 & 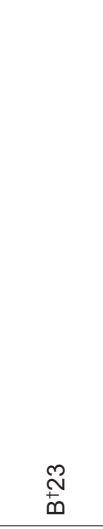 & 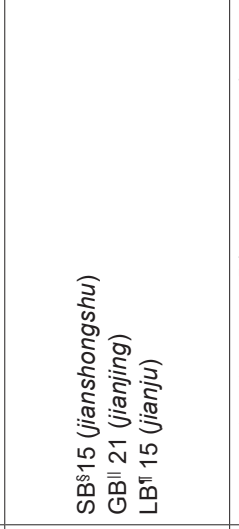 & 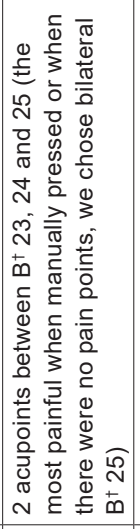 & 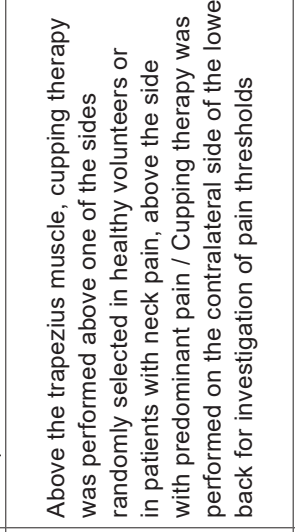 & 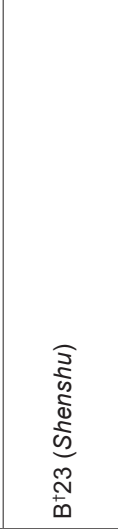 & $=$ \\
\hline 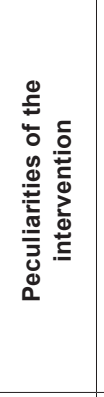 & $=$ & 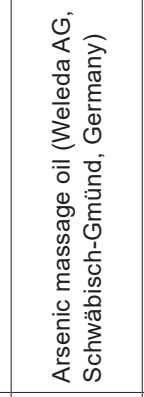 & 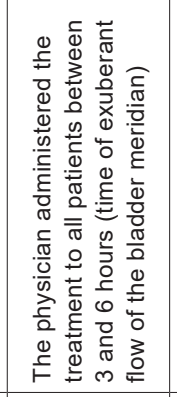 & $=$ & $=$ & 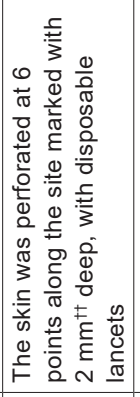 & 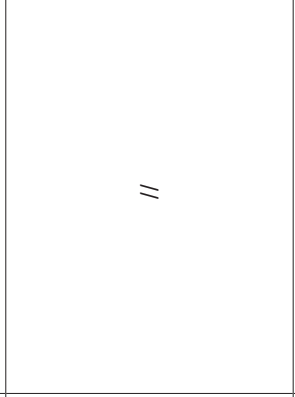 & $=$ & 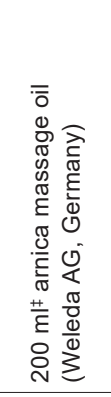 \\
\hline 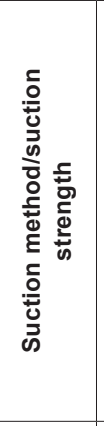 & 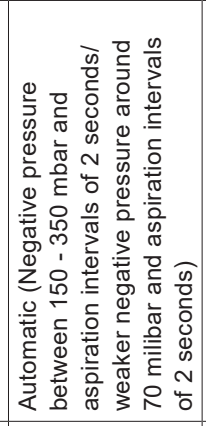 & 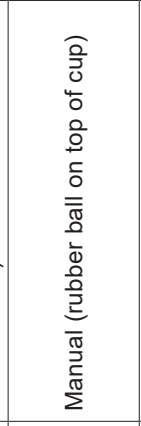 & 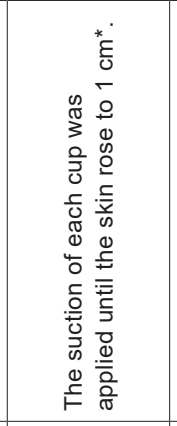 & $=$ & $\stackrel{\varrho}{\underline{\underline{*}}}$ & 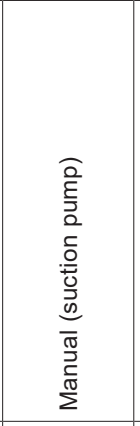 & 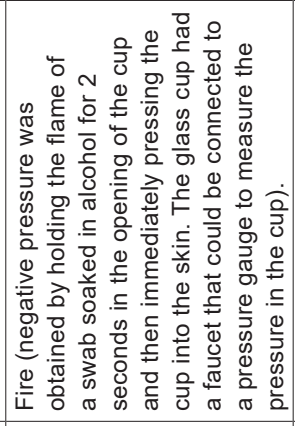 & 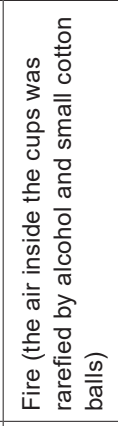 & $=$ \\
\hline 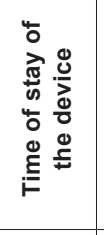 & 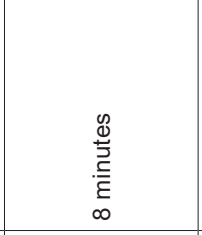 & 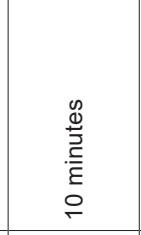 & 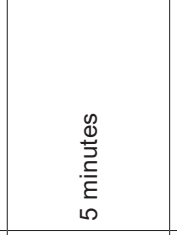 & 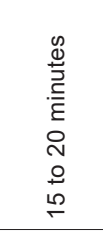 & 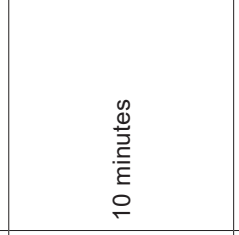 & 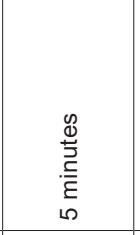 & 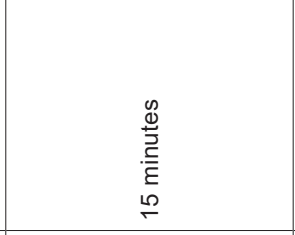 & 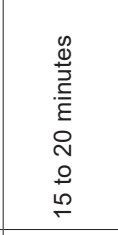 & 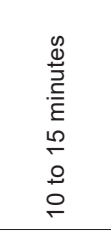 \\
\hline 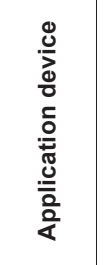 & 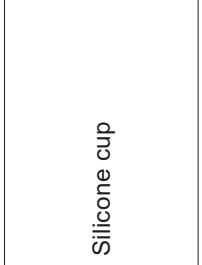 & 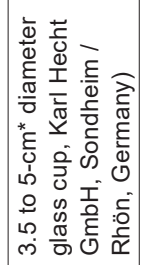 & 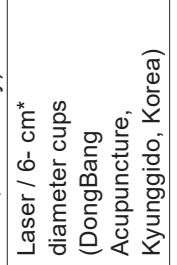 & $=$ & 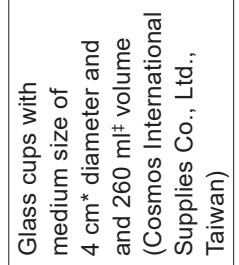 & 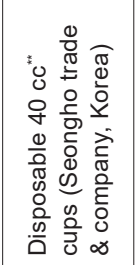 & 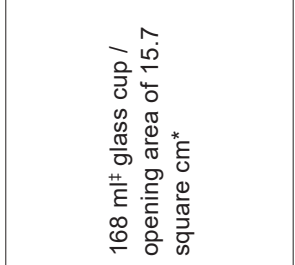 & 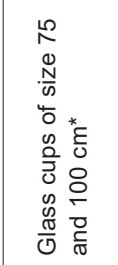 & 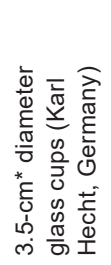 \\
\hline 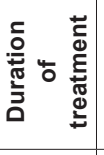 & 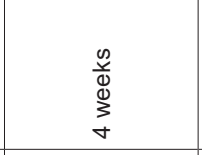 & 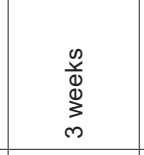 & $\begin{array}{l}\stackrel{\check{\Phi}}{\Phi} \\
\stackrel{\Delta}{3} \\
-\end{array}$ & 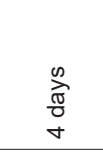 & 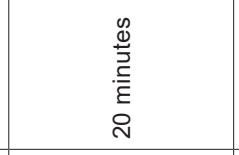 & 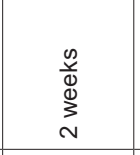 & 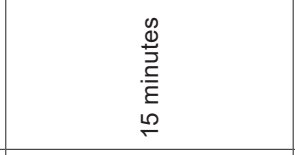 & 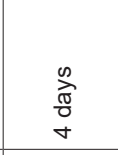 & 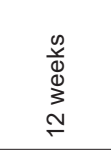 \\
\hline 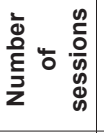 & $\infty$ & م & م & 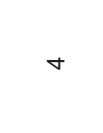 & $r$ & 0 & - & $\sigma$ & $\stackrel{\sim}{N}$ \\
\hline 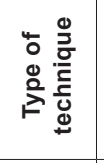 & 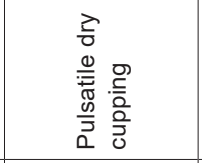 & 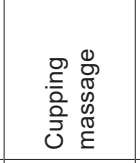 & 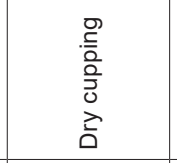 & 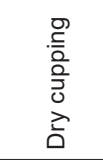 & 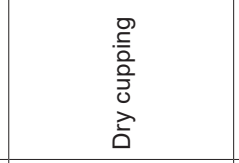 & $\begin{array}{l}\frac{0}{0} \\
\frac{0}{0} \\
\frac{0}{0} \\
\overline{0} \\
3 \\
3\end{array}$ & 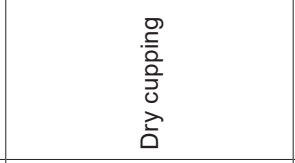 & 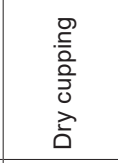 & 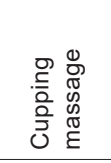 \\
\hline 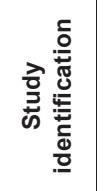 & 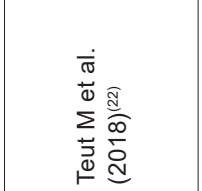 & 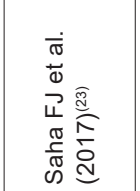 & 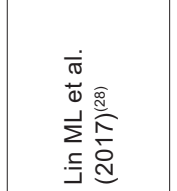 & 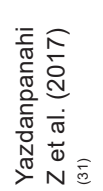 & 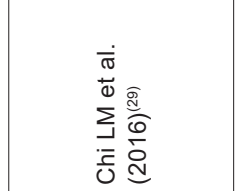 & 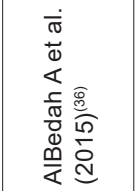 & 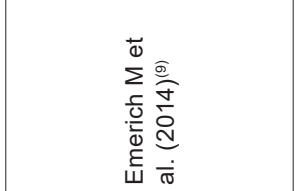 & 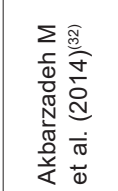 & 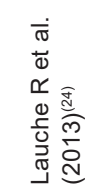 \\
\hline
\end{tabular}




\begin{tabular}{|c|c|c|c|c|c|c|c|}
\hline 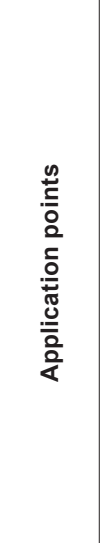 & 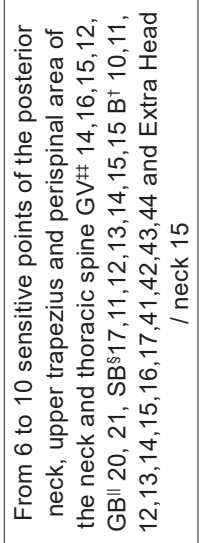 & 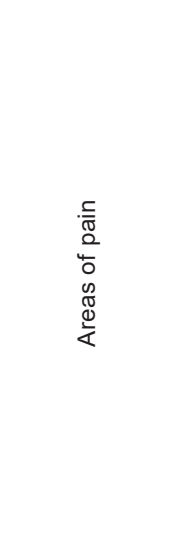 & 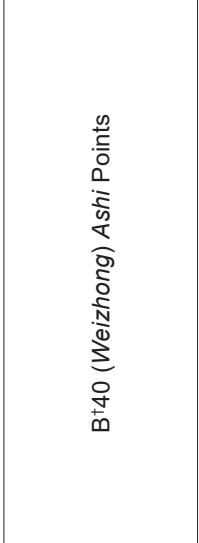 & 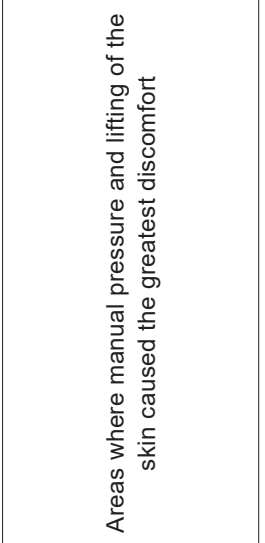 & 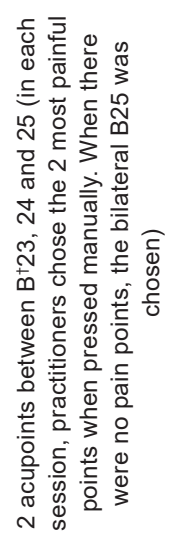 & 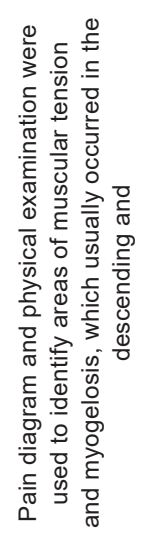 & 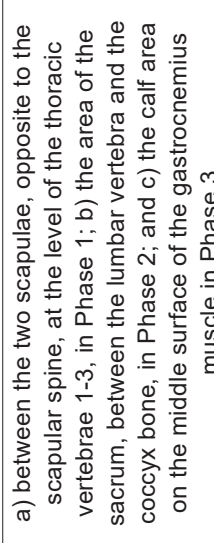 \\
\hline 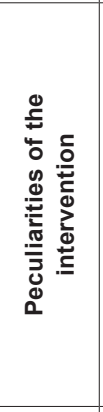 & 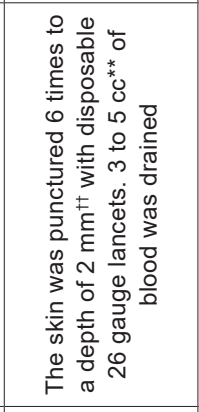 & 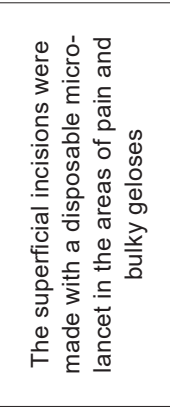 & $=$ & 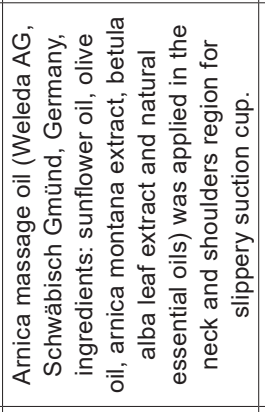 & 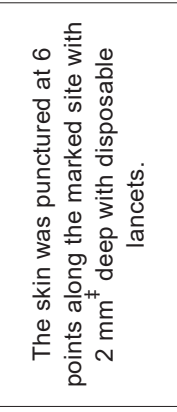 & $=$ & 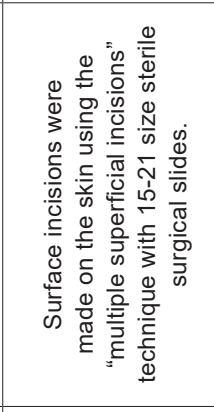 \\
\hline 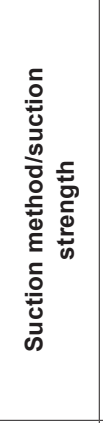 & 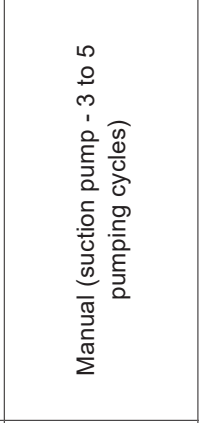 & 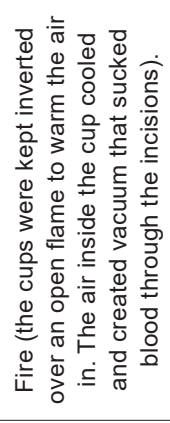 & $=$ & 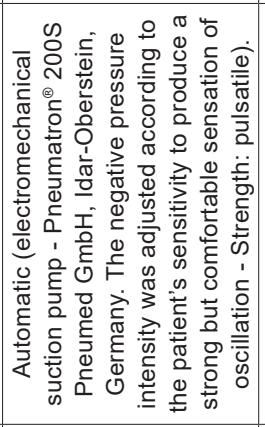 & 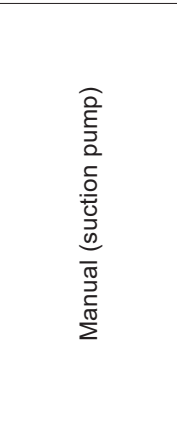 & 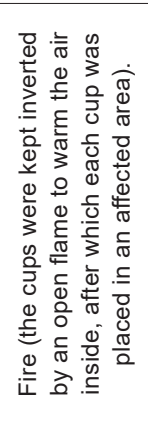 & 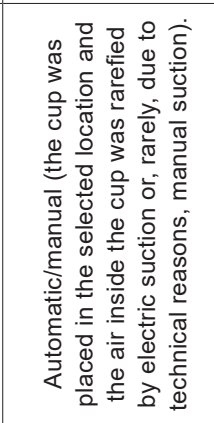 \\
\hline 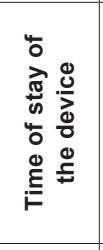 & 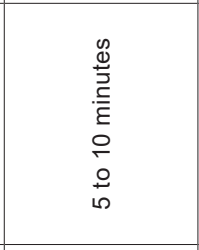 & 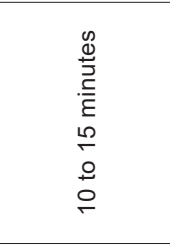 & 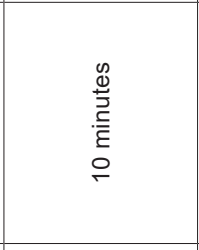 & 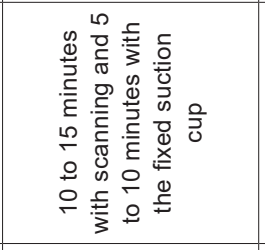 & 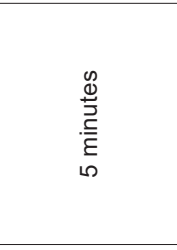 & 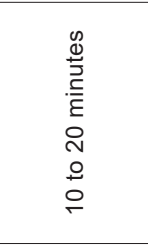 & 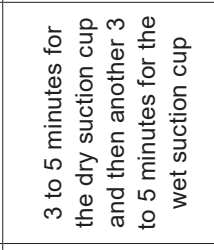 \\
\hline 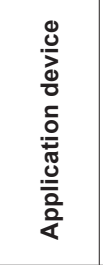 & 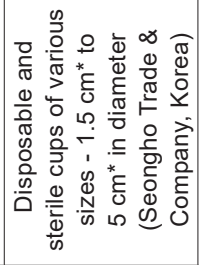 & 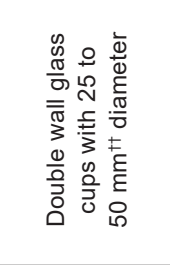 & 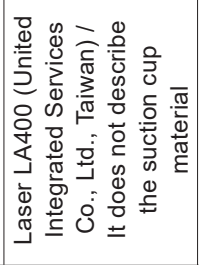 & 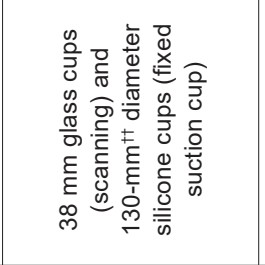 & 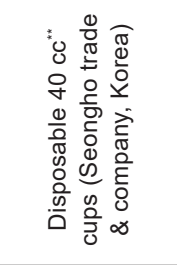 & 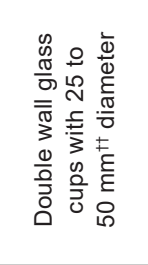 & 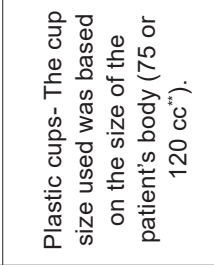 \\
\hline 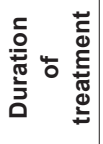 & 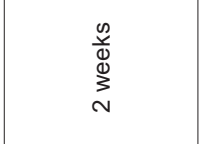 & 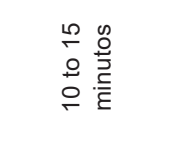 & 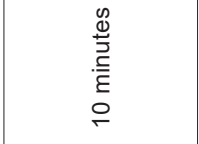 & 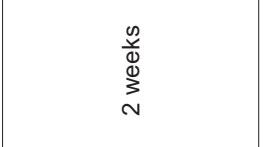 & & & 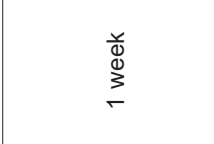 \\
\hline 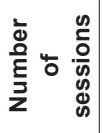 & 0 & - & - & ما & 0 & ه & $m$ \\
\hline 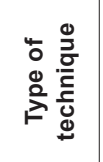 & 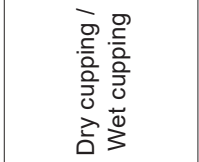 & 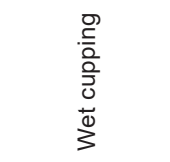 & 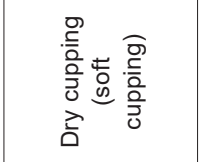 & 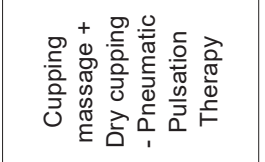 & 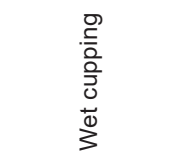 & 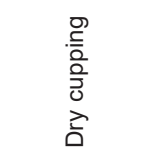 & 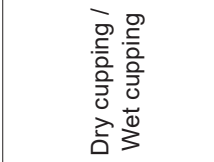 \\
\hline 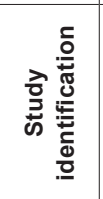 & 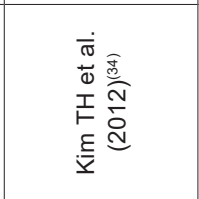 & 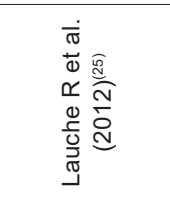 & 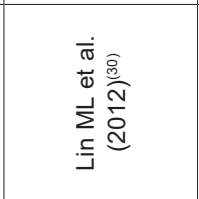 & 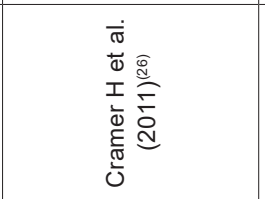 & 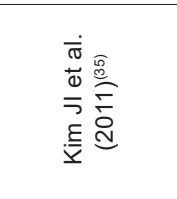 & 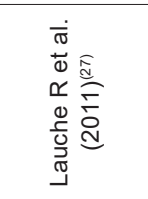 & 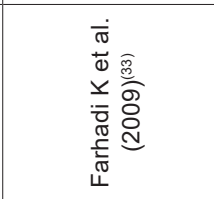 \\
\hline
\end{tabular}


The intervention was predominantly applied by physicians $(31.25 \% ; n=5)^{(22,25-28,34)}$; followed by nurses $(18.75 \% ; n=3)^{(22,29,32)}$ and pharmacists $(6.25 \% ; n=1)$ (32). And $25 \%$ of the studies $(n=4)^{(9,23,35-36)}$ reported that the intervention was performed by a therapist, without specifying the training area.

Only $18,75 \%$ of the studies ( $n=3$ ) presented the time of experience of the professional who performed the intervention, from three ${ }^{(35-36)}$ to four years ${ }^{(34)} ; 37.5 \%$ of the studies $(n=6)^{(9,22-25,27)}$ informed only that the intervention had been performed by experienced or trained professionals, but did not mention the time of training.

Of the 16 articles selected for the systematic review, 10 entered for meta-analysis that investigated the effectiveness of cupping therapy on pain intensity. All of them approached the outcome in two comparison groups (experimental and control), in evaluations performed before and immediately after the treatment. Five studies $^{(9,22,29,35-36)}$ did not enter because they did not have enough data for this analysis and one study ${ }^{(33)}$ performed the evaluation only three months after the end of treatment.

The results of the meta-analysis showed that cupping therapy was more effective in reducing pain compared to the control group (absolute difference between means: -1.59 , [95\% Confidence Interval: -2.07 to -1.10$] ; p=0.001)$, with moderate to high heterogeneity $\left(I^{2}=67.7 \%, p=0.001\right)$ (Figure 5$)$.
Study

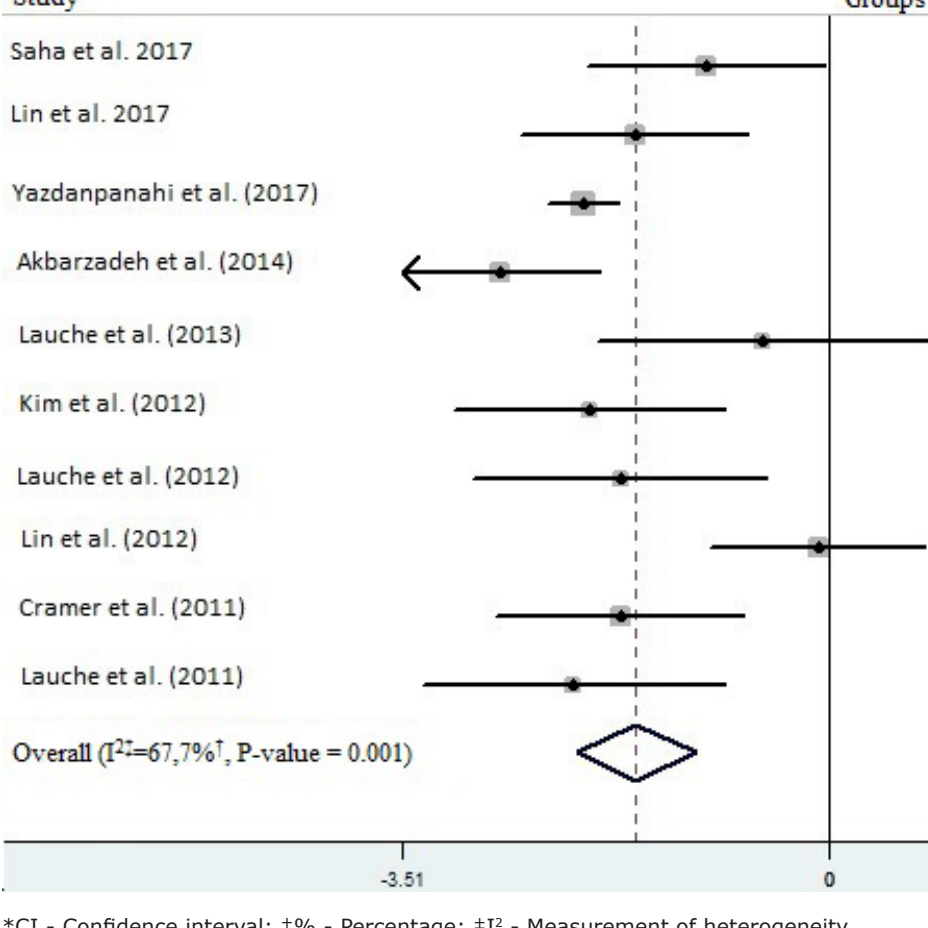

Sample Absolute differences Groups Experimental Control between means $\left(95 \%{ }^{\dagger} \mathrm{CI}^{*}\right.$ ) Weight $\%$

\begin{tabular}{|c|c|c|c|}
\hline 25 & 25 & $-1.01(-1.98,-0.04)$ & 9.97 \\
\hline 25 & 23 & $-1.60(-2.54,-0.68)$ & 10.28 \\
\hline 50 & 50 & $-2.02(-2.31,-1.73)$ & 15.68 \\
\hline 50 & 50 & $-2.70(-3.51,-1.89)$ & 11.37 \\
\hline 30 & 31 & $-0.54(-1.90,0.82)$ & 7.25 \\
\hline 20 & 20 & $-1.97(-3.09,-0.86)$ & 8.88 \\
\hline 22 & 23 & $-1.72(-2.92,-0.52)$ & 8.23 \\
\hline 28 & 29 & $-0.09(-0.97,0.79)$ & 10.75 \\
\hline 24 & 24 & $-1.72(-2.74,-0.70)$ & 9.61 \\
\hline 22 & 24 & $-2.10(-3.34,-0.86)$ & 8.01 \\
\hline 296 & 299 & $-1.59(-2.07,-1.10)$ & 100.00 \\
\hline
\end{tabular}

Figure 5 - Forest plot of the pain intensity score. Belo Horizonte, MG, Brazil, 2018

\section{Discussion}

Cupping therapy has shown positive results on chronic back pain in adults, not only in behavioral variables of pain, but also in physiological parameters in the majority of RCTs evaluated in this study, which contributes to the consolidation of its use in the treatment of this clinical condition in the study population.

Regarding methodological quality, most studies $^{(23,25-27,31-36)}$ obtained a median score (three) according to the Jadad scale(19). This score can be justified by the lack of masking of RCTs.

It is not feasible to conceal evaluation and intervention methods in cupping therapy ${ }^{(22)}$, since the marks left by the suction cups are often visible and may persist for several days, making it difficult to perform a masking process $^{(27)}$. Only one study ${ }^{(28)}$ achieved masking properly; however, it was true only for volunteers who received laser therapy, an intervention used concomitantly with cupping therapy, where sham laser acupuncture was performed by applying the same procedure in one of the groups, but without energy. In a second study ${ }^{(24)}$, there is a description that the masking was applied to the evaluator of the results; however, the application of suction cups causes marks (ecchymoses, petechiae) and one of the evaluated outcomes was the pain threshold, using the algometer; for this evaluation, as the area must be naked, the marks on the skin make this kind of masking impossible. Finally, 
in another study(22), the majority of participants in the minimal cupping group ( $84 \%$ ) was able to identify the allocation after four weeks, whereas in the cupping group $55 \%$ identified the allocation.

Regarding the evaluated outcomes, pain intensity predominated, which was measured mostly by means of the Visual Analogue Scale (VAS) ${ }^{(22-25,27-30,32)}$ and the Numerical Scale ${ }^{(26,34-36)}$, followed by the Neck Pain and Disability $\mathrm{Scale}^{(9)}$, by the short version of the McGill Pain Questionnaire(31), and by the Present Pain Intensity Scale(33).

Although there are variations, the VAS usually consists of scores of $0-10$ or $0-100$, the extreme left being described as no pain and the extreme right as the worst possible pain; the numerical scale has a numerical rating of $0-10,0-20$ or $0-100$. These scales can be classified as: painless (0), mild (1-3), moderate (4-6), and severe (7-10), and are frequently used in patients with chronic musculoskeletal pain ${ }^{(37)}$. In addition, some researchers ${ }^{(38-40)}$ have pointed to these two scales as the gold standard for assessing pain intensity, these being the instruments most used when evaluating adults, both in clinics and research.

Physical disability was the second most approached outcome, measured by means of the Neck Disability Index $(\mathrm{NDI})^{(23-27,34)}$, of the Oswestry Disability Questionnaire $(\mathrm{ODQ})^{(33,35-36)}$ and the Neck Pain and Disability Scale ${ }^{(9)}$. In fact, the severity and chronicity of back pain are associated with severe functional limitations ${ }^{(37)}$ that imply limitations in activities of daily living(41).

In addition, patients with chronic diseases, who require continuous treatment over a long period, present important changes in quality of life $^{(42)}$, being another important outcome to be evaluated, as occurred in six studies, through the Short Form 36 Health Survey Questionnaire (SF-36)(22-27).

Finally, the physiological parameter most evaluated in the studies was the nociceptive threshold before the mechanical stimulus, by means of a pressure algometer ${ }^{(9,23-27)}$. It is known that individuals who have pain in the spine have higher nociceptive sensitivity compared to healthy people ${ }^{(43)}$. However, this is still considered a subjective variable, since it is the patient who determines his/her pain threshold. In fact, when the evaluation process is more related to the symptoms, such as subjective phenomena, especially pain, than to physical or laboratory results, self-assessment is considered the most reliable indicator of the existence of pain ${ }^{(44)}$. Thus, the necessary information to carry out its evaluation has its origin in the individual's report ${ }^{(45)}$, who is the primary source of the assessment.

The systematized analysis of cupping therapy application methods showed that there is no standardization in the treatment protocol for chronic back pain. However, recent efforts have been made to standardize the cupping therapy procedure in general(46) and specifically for chronic back pain, since the most appropriate type of technique, duration of treatment, number of sessions, devices, time of application, method and suction strength and application points have not been determined.

It can be observed, however, that the most applied technique was dry cupping, specifically for the lumbar(22,28,30-32) and cervical regions ${ }^{(9,27,29,34)}$. This modality allows the stimulation of the acupoints in the same way as the acupuncture needles ${ }^{(47)}$. Researchers $^{(18)}$ suggest that laceration of the skin and capillaries, promoted by wet cupping, may act as another nociceptive stimulus that activates the descending inhibitory pathways of pain control(18), thus helping to treat chronic musculoskeletal conditions( ${ }^{(35)}$. However, risk for infection, vasovagal attacks and scars are the disadvantages of this method ${ }^{(18)}$. Still, compared to cupping massage, authors ${ }^{(47)}$ emphasize that dry cupping has a greater analgesic effect, since the use of lubricants can reduce the friction between the edge of the cup and the skin, a fact corroborated by some authors $^{(24)}$ who used arnica oil for the realization of cupping massage.

Despite the variability in the application of the intervention, it was possible to identify that, on average, the cupping therapy was applied in 5 sessions, with permanence of the cups in the skin for around 8 minutes, and interval of three to four days between the applications. According to some researchers ${ }^{(27)}$, at least five sessions are required for any significant effects of cupping treatment to appear, in addition to ensuring the feasibility of the RCT. Moreover, authors ${ }^{(47)}$ recommend that the cups should be left on the skin for 5 to 10 minutes or more, which culminates in the appearance of residual marks after treatment as a result of the rupture of small blood vessels that are painless and disappear between 1 and 10 days $^{(12)}$. Therefore, an interval between sessions is necessary in order to allow the reestablishment of the cutaneous and subcutaneous tissues.

Regarding the application cups, the disposable ones are preferable a high-level sterilization or disinfection process is required prior to reuse, since the pressure exerted may cause extravasation of blood and fluids from the skin ${ }^{(46)}$. Nowadays, cupping therapy has increasingly been performed with plastic cups ${ }^{(47)}$. The size of the cups varies according to the place of application, but it is often applied in places with abundant muscles, such as the back $^{(48)}$.

Regarding the suction method to create negative pressure, the use of fire predominated $(9,25,27,29,32)$, 
followed by manual pumping(23,34-36) and automatic pumping(22,26,33). Suction with fire is the traditional method used in China, however, there is a risk of burns ${ }^{(18)}$. Manual vacuum is created when using a suction pump. This method allows microcirculation to increase more effectively if compared to fire ${ }^{(18)}$. Finally, automatic pumping is created using an electric suction pump, which allows to adjust and measure the negative pressure inside the cup, being the most suitable method for scientific research(18).

Only three studies ${ }^{(22,26,28)}$ reported the suction strength used, which should be standardized in the application protocols. The suction can be light (100 and 300 millibar/one or two manual pumpings), medium (300 and 500 milibar/three or four manual pumpings), strong (above 500 milibar/five or more manual pumpings) or pulsatile (pressure inside the cups is variable, between 100 and 200 milibar every 2 seconds) $)^{(47,49)}$. The medium suction is often indicated for painful conditions of the musculoskeletal system ${ }^{(18)}$.

There was also no standardization in relation to the application points of cupping therapy. Despite this, the application in specific acupoints in the cervical region, mainly on the bladder, gallbladder and small intestine meridians, prevailed ${ }^{(29,34)}$, and in the lumbar region on the bladder meridian(30-32,35-36), followed by sensitive points ${ }^{(9,25-27,30)}$ named Ashi by TCM or trigger points by Western medicine.

Meridians are passages for the flow of "qi" (vital energy) and "xue" (blood), the two basic body fluids of TCM, which spread throughout the body surface, uniting the interior with the exterior of the body and connecting the internal organs, the joints and the extremities, transforming the whole body into a single organ ${ }^{(50)}$. Part of the meridians of the bladder, small intestine and gallbladder pass through the dorsal region. The acupuncture points are located in the meridians; besides local action, they also play a systemic action and reestablish the energy balance of the body by adjusting the function of the organs, maintaining homeostasis and treating the disease ${ }^{(51)}$, so the advantage in using them.

The trigger points or Ashi are specific points of high irritability; they are sensitive to digital pressure and can trigger local and referred pain ${ }^{(52)}$. They may be deriving from dynamic overload, such as trauma or overuse, or static overload, such as postural overloads occurring during daily activities and occupational activities(53), besides emotional tension. Addressing these points can also be a way to relieve local pain(54).

After the application of cupping therapy, both the acupoints of the meridians of the affected regions and the trigger points or Ashi may present bruising, erythema and/or ecchymoses. According to TCM, these signs represent stagnation of " $q i^{\prime}$ and/or " $x u e^{\text {" and may }}$ help the therapist in identifying body disorders.

Finally, the meta-analysis revealed a significant reduction of the pain intensity score in adults with chronic back pain by using cupping therapy ( $p=0.001)$. Compared with a control group (usual care/other intervention/waiting list), this modality has advantages in relieving pain, as can be seen in Figure 5 .

Only two studies ${ }^{(24,30)}$ did not present a statistically significant difference between the groups on the benefit or harm of this intervention (Figure 5). In fact, the first study ${ }^{(24)}$ pointed out that cupping therapy has the same effect as other intervention (progressive muscle relaxation) in reducing chronic nonspecific neck pain; despite this, cupping therapy was better than relaxation in improving well-being and decreasing sensitivity to pressure pain. The authors( ${ }^{(24)}$ justify this result, among other limitations, due to the fact that cupping therapy was performed by patients' relatives or friends at home. The second study ${ }^{(30)}$, despite having found a positive result on the intensity of pain, did not obtain a result in the meta-analysis. It is believed that this may have been due to the fact that both groups received the intervention of soft cupping and both obtained positive results.

In the other studies ${ }^{(23,25-28,31-32,34)}$, the intervention reduced the probability of the outcome, being the study with the largest sample ${ }^{(31)}$ the one the most contributed (15.68\% weight in the meta-analysis) for this (Figure 5). In fact, all these studies reported promising results of intervention on pain intensity.

However, the results of the effectiveness of cupping therapy still need to be confirmed by subgroup analyzes, based on different types of application techniques and control groups. In addition, it is important to perform meta-regression to find the source of heterogeneity of RCTs.

In a general way, the results showed a substantial variation in the application of cupping therapy, especially in relation to the type of technique, as well as differences in the control group, which made subgroup or metaregression unfeasible, respectively, due to the small number of studies with each of these specifications.

\section{Conclusion}

Cupping therapy is a promising method for the treatment and control of chronic back pain in adults, since it significantly decreases pain intensity scores when compared to control groups. However, the high heterogeneity and the median methodological quality of RCTs has limited the findings.

Despite this, a protocol can be established for this clinical condition: application of dry cupping technique 
in 5 sessions, with permanence of the disposable or plastic cups on the skin for about 8 minutes, preferably automatic or manual pumping, with medium suction strength, and three to seven days interval between applications. It is better to opt for acupoints of the dorsal region, especially those from the bladder meridian in the lumbar region, and for the meridians of the bladder, gallbladder and small intestine in the cervical and thoracic regions, as well as Ashi or trigger points. This protocol needs to be validated in future studies. And the main outcomes evaluated for this clinical condition were pain intensity, physical disability, quality of life and nociceptive threshold before the mechanical stimulus (pressure).

\section{Referências}

1. Sielski R, Rief W, Glombiewski JA. Efficacy of Biofeedback in Chronic back Pain: a Meta-Analysis. Int J Behav Med. [Internet]. 2017 [cited May 9, 2018];24(1):2541. Available from: https://link.springer.com/ article/10.1007\%2Fs12529-016-9572-9

2. Vos T, Barber RN, Bell B, Bertozzi-Villa A, Biryukov S, Bolliger I, et al. Global, regional, and national incidence, prevalence, and years lived with disability for 301 acute and chronic diseases and injuries in 188 countries, 19902013: a systematic analysis for the Global Burden of Disease Study 2013. Lancet. [Internet]. 2015 [cited May 9, 2018];386(9995):743-800. Available from: https://www. ncbi.nlm.nih.gov/pmc/articles/PMC4561509/

3. Bergström G, Hagberg J, Busch $H$, Jensen I, Björklund C. Prediction of sickness absenteeism, disability pension and sickness presenteeism among employees with back pain. J Occup Rehabil. [Internet]. 2014 [cited May 9, 2018];24(2):278-86. Available from: https://www.ncbi. nlm.nih.gov/pmc/articles/PMC4000420/

4. Gore M, Sadosky A, Stacey BR, Tai KS, Leslie D. The burden of chronic low back pain: clinical comorbidities, treatment patterns, and health care costs in usual care settings. Spine. [Internet]. 2012 [cited May 9, 2018];37(11):E668-77. Available from: https://insights. ovid.com/pubmed?pmid=22146287

5. Sita Ananth M. 2010 Complementary Alternative Medicine Survey of Hospitals - Summary of Results. [Internet]. Alexandria, VA: Samueli Institute; 2011 [cited May 13, 2018]. Available from: https://allegralearning.com/wpcontent/uploads/2015/06/CAM-Survey-FINAL-2011.pdf 6. Wang YT, Qi Y, Tang FY, Li FM, Li QH, Xu CP, et al. The effect of cupping therapy for low back pain: A meta-analysis based on existing randomized controlled trials. J Back Musculoskelet Rehabil. [Internet]. 2017 [cited May 13, 2018];30(6):1187-95. Available from: https://content. iospress.com/articles/journal-of-back-and-musculoskeletalrehabilitation/bmr169736

7. Aboushanab TS, AISanad S. Cupping Therapy: An Overview From A Modern Medicine Perspective. J Acupunct Meridian Stud. [Internet]. 2018 [cited May 13, 2018]; S20052901(17):30204-2. Available from: https://www.jams-kpi. com/article/S2005-2901(17)30204-2/pdf

8. Cao H, Li X, Yan X, Wang NS, Bensoussan A, Liu J. Cupping therapy for acute and chronic pain management: a systematic review of randomized clinical trials. J Tradit Chin Med. [Internet]. 2014 [cited May 13, 2018];1(1):49-61. Available from: https://ac.els-cdn.com/S2095754814000040/1s2.0-S2095754814000040-main.pdf?_tid=c1e983c664eb-465c-9208-08657cacb479\&acdnat $=1526231974$ f88ac1fbce7d2ac75da5b3f28000df71

9. Emerich M, Braeunig M, Clement HW, Lüdtke R, Huber R. Mode of action of cupping--local metabolism and pain thresholds in neck pain patients and healthy subjects. Complement Ther Med. [Internet]. 2014 [cited May 13, 2018];22(1):148-58. Available from: https://www.sciencedirect.com/science/ article/pii/S0965229913002112?via\%3Dihub

10. Kheirandish H, Shojaeeefar E, Meysamie A. Role of Cupping in the treatment of different diseases:systematic review article. Tehran Univ Med J. [Internet]. 2017 [cited May 13, 2018];74(12):829-42. Available from: http://tumj. tums.ac.ir/article-1-7880-en.html.

11. Rozenfeld E, Kalichman L. New is the well-forgotten old: The use of dry cupping in musculoskeletal medicine. J Bodyw Mov Ther. [Internet]. 2016 [cited May 13, 2018];20(1):173-8. Available from: https://www.bodyworkmovementtherapies. com/article/S1360-8592(15)00279-X/pdf

12. Markowski A, Sanford S, Pikowski J, Fauvell D, Cimino D, Caplan S. A Pilot Study Analyzing the Effects of Chinese Cupping as an Adjunct Treatment for Patients with Subacute Low Back Pain on Relieving Pain, Improving Range of Motion, and Improving Function. J Altern Complement Med. [Internet]. 2014 [cited May 13, 2018];20(2):113-7. Available from: https://www.liebertpub.com/doi/abs/10.1089/ acm.2014.5302.abstract

13. Moher D, Liberati A, Tetzlaff J, Altman DG, The PRISMA Group. Preferred Reporting Items for Systematic Reviews and Meta-Analyses: The PRISMA Statement. PLoS Med. [Internet]. 2009 [cited May 13, 2018];6(7):e1000097. Available from: https://www.ncbi.nlm.nih.gov/pmc/articles/ PMC2707599/pdf/pmed.1000097.pdf

14. Higgins JPT, Green S (editors). Cochrane Handbook for Systematic Reviews of Interventions Version 5.1.0. The Cochrane Collaboration; 2011. Available from: http:// handbook-5-1.cochrane.org/

15. Merskey $H$, Bogduk N (editors). Classification of chronic pain. Descriptions of chronic pain syndromes and definitions of pain terms. 2nd ed. Prepared by Task Force on Taxonomy of the International Association for the Study of Pain. 
[Internet]. 2002 [cited May 13, 2018]. 238p. Available from: https://www.iasp-pain.org/files/Content/ContentFolders/ Publications2/FreeBooks/Classification-of-Chronic-Pain.pdf 16. Moura CC, Carvalo CC, Silva AM, Iunes DH, Carvalho EC, Chaves ECL. Effect of auriculotherapy on anxiety. Rev Cuba Enferm. [Internet]. 2014 [cited May 13, 2018]; 30 (2):1-15. Available from: http://www.medigraphic.com/ pdfs/revcubenf/cnf-2014/cnf142e.pdf

17. MacPherson $H$, Altman DG, Hammerschlag R, Youping $L$, Taixiang W, White A, et al. Revised Standards for Reporting Interventions in Clinical Trials of Acupuncture (STRICTA): Extending the CONSORT Statement. PLoS Med. [Internet]. 2010 [cited May 13, 2018];7(6):1-11. Available from: https://www.ncbi.nlm.nih.gov/pmc/articles/PMC2882429/ pdf/pmed.1000261.pdf

18. Al-Bedah AM, Aboushanab TS, Alqaed MS, Qureshi NA, Suhaibani I, Ibrahim G, et al. Classification of Cupping Therapy: A Tool for Modernization and Standardization. JOCAMR. [Internet]. 2016 [cited May 13, 2018];1(1):110. Available from: https://www.researchgate.net/ publication/306240082_Classification_of_Cupping_ Therapy_A_Tool_for_Modernization_and_Standardization 19. Jadad AR, Moore RA, Carroll D, Jenkinson C, Reynolds DJ, Gavaghan DJ, et al. Assessing the Quality of Reports of Randomized Clinical Trials: Is Blinding Necessary? Control Clin Trials. [Internet]. 1996 [cited May 13, 2018];17(1):112. Available from: https://www.sciencedirect.com/science/ article/pii/0197245695001344?via\%3Dihub

20. Lau J, Ioannidis JP, Schmid CH. Quantitative synthesis in systematic reviews. Ann Intern Med. [Internet]. 1997 [cited May 13, 2018];127(9):820-6. Available from: http://annals. org/aim/article-abstract/710939/quantitative-synthesissystematic-reviews volume $=127 \&$ issue $=9$ \&page $=820$

21. Higgins JPT, Thompson SG. Quantifying heterogeneity in a meta-analysis. Statist. Med. [Internet]. 2002 [cited May 13, 2018];21:1539-58. Available from: https://pdfs.semanticscholar.org/d76b/ de423b71f1cb900b988311bd2d71b700d506.pdf

22. Teut M, Ullmann A, Ortiz M, Rotter G, Binting S, Cree $M$, et al. Pulsatile dry cupping in chronic low back pain a randomized three-armed controlled clinical trial. BMC Complement Altern Med. [Internet]. 2018 [cited May 13, 2018];18(1):115. Available from: https://www.ncbi.nlm. nih.gov/pmc/articles/PMC5879872/pdf/12906_2018_ Article_2187.pdf

23. Saha FJ, Schumann S, Cramer H, Hohmann C, Choi KE, Rolke $\mathrm{R}$, et al. The Effects of Cupping Massage in Patients with Chronic Neck Pain - A Randomised Controlled Trial. Complement Med Res. [Internet]. 2017 [cited May 13, 2018];24(1):26-32. Available from: https://www.karger. com/Article/Pdf/454872

24. Lauche R, Materdey S, Cramer $H$, Haller $H$, Stange $R$, Dobos $G$, et al. Effectiveness of home- based cupping massage compared to progressive muscle relaxation in patients with chronic neck pain - a randomized controlled trial. PLoS One. [Internet]. 2013 [cited May 13, 2018];8(6):1-9. Available from: https://www.ncbi.nlm.nih.gov/pmc/articles/ PMC3676414/pdf/pone.0065378.pdf

25. Lauche R, Cramer H, Hohmann C, Choi KE, Rampp T, Saha FJ, et al. The effect of traditional cupping on pain and mechanical thresholds in patients with chronic nonspecific neck pain: a randomised controlled pilot study. Evid Based Complement Alternat Med. [Internet]. 2012 [cited May 13, 2018];2012:1-10. Available from: https://www.ncbi.nlm.nih. gov/pmc/articles/PMC3235710/pdf/ECAM2012-429718.pdf 26. Cramer H, Lauche R, Hohmann C, Choi KE, Rampp $T$, Musial $F$, et al. Randomized controlled trial of pulsating cupping (pneumatic pulsation therapy) for chronic neck pain. Forsch Komplementmed. [Internet]. 2011 [cited May 13, 2018];18(6):327-34. Available from: https://www.karger. com/Article/Abstract/335294

27. Lauche R, Cramer H, Choi KE, Rampp T, Saha FJ, Dobos $\mathrm{G}$, et al. The influence of a series of five dry cupping treatments on pain and mechanical thresholds in patients with chronic non-specific neck pain-a randomised controlled pilot study. BMC Complement Altern Med. [Internet]. 2011 [cited May 13, 2018];18(6):327-34. Available from: https:// www.ncbi.nlm.nih.gov/pmc/articles/PMC3224248/pdf/14726882-11-63.pdf

28. Lin ML, Wu JH, Lin CW, Su CT, Wu HC, Shih YS, et al. Clinical Effects of Laser Acupuncture plus Chinese Cupping on the Pain and Plasma Cortisol Levels in Patients with Chronic Nonspecific Lower Back Pain: A Randomized Controlled Trial. Evid Based Complement Alternat Med. [Internet]. 2017 [cited May 13, 2018];2017:1-8. Available from: https:// www.hindawi.com/journals/ecam/2017/3140403/

29. Chi LM, Lin LM, Chen CL, Wang SF, Lai HL, Peng TC. The Effectiveness of Cupping Therapy on Relieving Chronic Neck and Shoulder Pain: A Randomized Controlled Trial. Evid Based Complement Alternat Med. [Internet]. 2016 [cited May 13, 2018];2016:1-7. Available from: https://www. hindawi.com/journals/ecam/2016/7358918/

30. Lin ML, Wu HC, Hsieh YH, Su CT, Shih YS, Lin CW, et al. Evaluation of the effect of laser acupuncture and cupping with ryodoraku and visual analog scaleon low back pain. Evid Based Complement Alternat Med. [Internet]. 2012; [cited May 13, 2018]2012:1-7. Available from: https://www.ncbi. nlm.nih.gov/pmc/articles/PMC3482015/pdf/ECAM2012521612.pdf

31. Yazdanpanahi Z, Ghaemmaghami M, Akbarzadeh M, Zare N, Azisi A. Comparison of the Effects of Dry Cupping and Acupressure at Acupuncture Point (BL23) on the Women with Postpartum Low Back Pain (PLBP) Based on Short Form McGill Pain Questionnaires in Iran: A Randomized Controlled Trial. J Fam Reprod Health. [Internet]. 2017 [cited May 13, 
2018];11(2):82-9. Available from: https://www.ncbi.nlm. nih.gov/pmc/articles/PMC5742668/pdf/JFRH-11-82.pdf

32. Akbarzadeh M, Ghaemmaghami M, Yazdanpanahi Z, Zare N, Azizi A, Mohagheghzadeh A. The Effect Dry Cupping Therapy at Acupoint BL23 on the Intensity of Postpartum Low Back Painin Primiparous Women Based on Two Types of Questionnaires, 2012; A Randomized ClinicalTrial. Int J Community Based Nurs Midwifery. [Internet]. 2014 [cited May 13, 2018];2(2):112-20. Available from: https:// www.ncbi.nlm.nih.gov/pmc/articles/PMC4201191/pdf/ ijcbnm-2-112.pdf

33. Farhadi K, Schwebel DC, Saeb M, Choubsaz M, Mohammadi R, Ahmadi A. The effectiveness of wetcupping for nonspecific low back pain in Iran: a randomized controlledtrial. Complement Ther Med. [Internet]. 2009 [cited May 13, 2018];17(1):9-15. Available from: https://www.sciencedirect.com/science/article/pii/ S0965229908000630?via\%3Dihub

34. Kim TH, Kang JW, Kim KH, Lee MH, Kim JE, Kim JH, et al. Cupping for treating neck pain in video display terminal (VDT) users: a randomized controlled pilot trial. J Occup Health. [Internet]. 2012 [cited May 13, 2018];54(6):41626. Available from: https://www.jstage.jst.go.jp/article/ joh/54/6/54_12-0133-OA/_pdf/-char/en

35. Kim JI, Kim TH, Lee MS, Kang JW, Kim KH, Choi JY, et al. Evaluation of wet-cupping therapy for persistent nonspecific low back pain: a randomised, waiting-list controlled, open-label, parallel-group pilot trial. Trials. [Internet]. 2011 [cited May 13, 2018];12:146. Available from: https://www. ncbi.nlm.nih.gov/pmc/articles/PMC3141528/pdf/1745-621512-146.pdf

36. AlBedah A, Khalil M, Elolemy A, Hussein AA, AIQaed M, Al Mudaiheem $A$, et al. The Use of Wet Cupping for Persistent Nonspecific Low Back Pain: Randomized Controlled Clinical Trial. J Altern Complement Med. [Internet]. 2015 [cited May 13, 2018];21(8):504-8. Available from: https:// www.ncbi.nlm.nih.gov/pmc/articles/PMC4522952/pdf/ acm.2015.0065.pdf

37. Salaffi F, Ciapetti A, Carotti M. Pain assessment strategies in patients with musculoskeletal conditions. Reumatismo. [Internet]. 2012 [cited May 13, 2018];64(4):216-29. Available from: http://reumatismo.org/index.php/reuma/ article/view/reumatismo.2012.216/pdf

38. Puntillo K, Neighbor M, Nixon R. Accuracy of emergency nurses in assessment of patients pain. Pain Manag Nurs. [Internet]. 2003 [cited May 13, 2018];4(4):171-5. Available from: http://allnurses.com/pain-management-nursing/ accuracy-of-emergency-59028.html

39. Dworkin RH, Turk DC, Farrar JT, Haythornthwaite JA, Jensen MP, Katz NP, et al. Core outcome measures for chronic pain clinical trials: IMMPACT recommendations. Pain. [Internet]. 2005 [cited May 13, 2018];113:9-19.
Available from: http://www.immpact.org/static/publications/ Dworkin\%20et\%20al.,\%202005.pdf

40. Breivik H, Borchgrevink PC, Allen SM, Rosseland LA, Romundstad L, Hals EK, et al. Assessment of pain. Br J Anaesth. [Internet]. 2008 [cited May 13, 2018]; 101(1):1724. Available from: https://bjanaesthesia.org/article/S00070912(17)34263-0/pdf

41. Cunha LL, Mayrink WC. Influence of chronic pain in the quality of life of the elderly. Rev Dor. [Internet]. 2011 [cited May 13, 2018];12(2):120-4. Available from: http://www. scielo.br/pdf/rdor/v12n2/v12n2a08.pdf

42. Castro MMC, Daltro C, Kraychete DC, Lopes J. The cognitive behavioral therapy causes an improvement in quality of life in patients with chronic musculoskeletal pain. Arq Neuro-psiquiatr. [Internet]. 2012 [cited May 13, 2018];70(11):864-8. Available from: http://www. scielo.br/pdf/anp/v70n11/a08v70n11.pdf

43. Farasyn A, Lassat B. Cross friction algometry (CFA): Comparison of pressure pain thresholds between patients with chronic non-specific low back pain and healthy subjects. J Bodyw Mov Ther. [Internet]. 2016 [cited May 13, 2018];20(2):224-34. Available from: https://www.bodyworkmovementtherapies.com/article/ S1360-8592(15)00259-4/pdf

44. National Institutes of Health. Consensus Development Conference Statement. [Internet]. The Integrated Approach to the Management of Pain. May 19-21, 1986 [cited May 13, 2018]. Available from: http://consensus. nih.gov/1986/1986PainManagement055html.htm 45. Sousa FAEF, Pereira LV, Cardoso R, Hortense P. Multidimensional pain evaluation scale. (EMADOR). Rev. Latino-Am. Enfermagem. [Internet]. 2010 [cited May 13, 2018];18(1):1-9. Available from: http://www. scielo.br/pdf/rlae/v18n1/pt_02.pdf

46. Nielsen A, Kligler B, Koll BS. Safety protocols for gua sha (press-stroking) and baguan (cupping). Complement Ther Med. [Internet]. 2012 [cited May 13, 2018];20(5):340-4. Available from: https://www.sciencedirect.com/science/article/pii/ S0965229912000829?via\%3Dihub

47. Tham LM, Lee HP, Lu C. Cupping: From a biomechanical perspective. J Biomech. [Internet]. 2006 [cited May 13, 2018];39(12):2183-93. Available from: https://www. jbiomech.com/article/S0021-9290(05)00322-2/pdf 48. Yoo, S.S., Tausk, F., 2004. Cupping: east meets west. Int J Dermatol. [Internet]. 2004 [cited May 13, 2018];43(9):664-5. Available from: https://onlinelibrary. wiley.com/doi/abs/10.1111/j.1365-4632.2004.02224.x 49. Teut M, Kaiser S, Ortiz M, Roll S, Binting S, Willich SN, et al. Pulsatile dry cupping in patients with osteoarthritis of the knee - a randomized controlled exploratory trial. BMC Complement Altern Med. [Internet]. 2012 [cited May 13, 2018];12(184):1-9. Available from: https:// 
www.ncbi.nlm.nih.gov/pmc/articles/PMC3527288/ pdf/1472-6882-12-184.pdf

50. Wang GJ, Ayati MH, Zhang WB. Meridian studies in China: a systematic review. J Acupunct Meridian Stud. [Internet]. 2010 [cited May 13, 2018];3(1):1-9. Available from: https:// www.jams-kpi.com/article/S2005-2901(10)60001-5/pdf 51. Li F, He T, Xu Q, Lin LT, Li H, Liu Y, et al. What is the Acupoint? A preliminary review of Acupoints. Pain Med. [Internet]. 2015 [cited May 13, 2018];16(10):1905-15. Available from: https://academic.oup.com/painmedicine/ article/16/10/1905/2460295

52. International Association for the Study of Pain [Internet]. Global year against musculoskeletal pain. October 2009 - October 2010. Myofascial Pain. 2010 [cited May 13, 2018]. Available from: http://www.iasp-pain.org/ files/Content/ContentFolders/GlobalYearAgainstPain2/ MusculoskeletalPainFactSheets/MyofascialPain_Final.pdf 53. Dommerholt J. Dry needling - peripheral and central considerations. Pain Med. [Internet]. 2015 [cited May 13, 2018];16(10):1905-15. Available from: https:// www.ncbi.nlm.nih.gov/pmc/articles/PMC3201653/pdf/ jmt-19-04-223.pdf

54. Zhao H. Clinical observation on therapeutic effect of cupping combined with acupuncture stimulation at trigger points for lumbar myofascial pain syndrome. Zhen Ci Yan Jiu. [Internet]. 2014 [cited May 13, 2018];39(4):324-8. Available from: https://web.b.ebscohost.com/abstract? direct $=$ true $\&$ profile $=$ ehost $\&$ scope $=$ site \&authtype $=$ crawler\&jrnl=10471979\&AN=123067289\&h= KVyuzUBFiXE6HntiPqHImXntz1iicxcKNwGrIQq0AM eIF2V6vP7ve956sIg8M0zmRdGAVvtrgKrGNtqZ4USF4 $\mathrm{g} \% 3 \mathrm{~d} \% 3 \mathrm{~d} \& \mathrm{crl}=\mathrm{c} \&$ resultNs=AdminWebAuth\&resultLocal $=$ ErrCrINotAuth\&crlhashurl=login.aspx\%3fdirect\%3dtrue $\% 26$ profile\%3dehost\%26scope\%3dsite\%26authtype\% 3dcrawler\%26jrnl\%3d10471979\%26AN\%3d123067289 Creative Commons (CC BY).

This license lets others distribute, remix, tweak, and build upon your work, even commercially, as long as they credit you for the original creation. This is the most accommodating of licenses offered. Recommended for maximum dissemination and use of licensed materials. 